\title{
Mechanisms of $\mathbf{T}$ cell organotropism
}

\author{
Hongmei $\mathrm{Fu}^{1} \cdot$ Eleanor Jayne Ward ${ }^{1} \cdot$ Federica M. Marelli-Berg $^{1}$
}

Received: 25 February 2016/Revised: 21 March 2016/Accepted: 22 March 2016/Published online: 1 April 2016

(c) The Author(s) 2016. This article is published with open access at Springerlink.com

\begin{abstract}
Protective immunity relies upon $\mathrm{T}$ cell differentiation and subsequent migration to target tissues. Similarly, immune homeostasis requires the localization of regulatory $\mathrm{T}$ cells (Tregs) to the sites where immunity takes place. While naïve $\mathrm{T}$ lymphocytes recirculate predominantly in secondary lymphoid tissue, primed $\mathrm{T}$ cells and activated Tregs must traffic to the antigen rich non-lymphoid tissue to exert effector and regulatory responses, respectively. Following priming in draining lymph nodes, $\mathrm{T}$ cells acquire the 'homing receptors' to facilitate their access to specific tissues and organs. An additional level of topographic specificity is provided by $\mathrm{T}$ cells receptor recognition of antigen displayed by the endothelium. Furthermore, co-stimulatory signals (such as those induced by $\mathrm{CD} 28$ ) have been shown not only to regulate T cell activation and differentiation, but also to orchestrate the anatomy of the ensuing $\mathrm{T}$ cell response. We here review the molecular mechanisms supporting trafficking of both effector and regulatory $\mathrm{T}$ cells to specific antigen-rich tissues.
\end{abstract}

Keywords Homing receptors - T lymphocytes ·

$\mathrm{T}$ cell migration $\cdot$ Organotropism

\section{Abbreviations}

$\begin{array}{ll}\text { ACD } & \text { Allergic contact dermatitis } \\ \text { Ang II } & \text { Angiotensin II }\end{array}$

Federica M. Marelli-Berg

f.marelli-berg@qmul.ac.uk

William Harvey Research Institute, Heart Centre, Barts and the London School of Medicine and Dentistry, Queen Mary University of London, Charterhouse Square, London EC1M 6BQ, UK

\begin{tabular}{ll} 
APCs & Antigen presenting cells \\
BATF & Basic leucine zipper transcription factor \\
CLA & Cutaneous lymphocyte-associated antigen \\
CNS & Central nervous system \\
CTLA-4 & Cytotoxic T lymphocytes antigen 4 \\
DCs & Dendritic cells \\
DETCs & Dendritic epidermal T cells \\
EAE & Experimental autoimmune encephalomyelitis \\
ECs & Endothelial cells \\
FoxP3 & Forkhead Box P3 \\
GALT & Gut-associated lymphoid tissue \\
GPR & G protein-coupled receptor \\
GVHD & Graft-versus-host disease \\
HGF & Hepatocyte growth factor \\
HIV & Human immunodeficiency virus \\
HSV & Herpes simplex virus \\
IELs & Intraepithelial lymphocytes \\
IPEX & Immune polyendocrine enteropathy X-linked \\
& syndrome \\
KLF2 & Krüppel-like factor 2 \\
LFA & Lymphocyte function-associated antigen \\
LNs & Lymph nodes \\
LP & Lamina propria \\
MAdCAM-1 & Mucosal addressin cell adhesion molecule-1 \\
MHC & Major histocompatibility complex \\
MLCs & Memory lymphocyte clusters \\
MLNs & Mesenteric lymph nodes \\
MMP & Matrix metalloproteinases \\
mTOR & Mammalian target of rapamycin \\
NOD & Non-obese diabetic \\
PLNs & Peripheral lymph nodes \\
PI3K & Phosphatidylinositol-3'-kinase \\
PNAd & Peripheral lymph node addressin \\
PSGL-1 & P-selectin glycoprotein ligand-1 \\
PPs & Peyer's patches \\
& \\
\hline
\end{tabular}

APCs

CLA

CNS

As-

DETCs

FoxP3

GALT

HGF

HIV

KLF2

LFA

LNs

MAdCAM-1

MHC

MLCs

MLNs

MMP

mTOR

NOD

PLNs

PI3K

PSGL-1

PPs 


$\begin{array}{ll}\text { RA } & \text { Retinoic acid } \\ \text { RAR } & \text { Retinoic acid receptor } \\ \text { RALDH } & \text { Retinaldehyde dehydrogenase } \\ \text { S1PR1 } & \text { Sphingosine-1-phosphate receptor 1 } \\ \text { S1P } & \text { Sphingosine-1 phosphate } \\ \text { SDF-1 } & \text { Stromal-derived factor-1 } \\ \text { SLOs } & \text { Secondary lymphoid organs } \\ \text { TEM } & \text { Trans-endothelial migration } \\ \text { TGF- } \beta & \text { Transforming growth factor beta } \\ \mathrm{T}_{\text {CM }} & \text { Central memory T cells } \\ \mathrm{T}_{\text {EFF }} & \text { Effector T cells } \\ \mathrm{T}_{\text {EM }} & \text { Effector memory T cells } \\ \mathrm{T}_{\mathrm{RM}} & \text { Tissue resident memory T cells } \\ \text { Th } & \text { T helper cells } \\ \text { Tregs } & \text { Regulatory T cells } \\ \text { iTregs } & \text { Induced Tregs } \\ \text { nTregs } & \text { Naturally occurring Tregs } \\ \text { VA } & \text { Vitamin A } \\ \text { VCAM-1 } & \text { Vascular cell adhesion molecule-1 } \\ \text { VLA } & \text { Very late antigen (VLA) }\end{array}$

\section{Introduction: lymphocyte recirculation and homing}

Effective immune surveillance relies on the continuous trafficking of lymphocytes through blood, lymphoid organs and non-lymphoid tissue in a process known as recirculation [1]. The physiological process by which lymphocytes leave circulation, cross endothelium, find and localize to particular tissues is known as extravasation [2]. In healthy tissue, the vascular endothelium forms a non-thrombotic, non-adhesive barrier, and is impermeable to macromolecules [3]. Upon inflammation, endothelial cells (ECs) undergo physiological and molecular changes such as the up-regulation of adhesion molecule expression. This in turn allows the exit of lymphocytes across the endothelium into the tissue without disrupting endothelial integrity.

The initial stage of lymphocyte trafficking is mostly mediated by selectins, which are responsible for lymphocyte transient tethering and rolling on the endothelium [4]. This initial contact between the circulating lymphocytes and the endothelium monolayer facilitates lymphocyte exposure to chemokines displayed on the EC surface, which induces intracellular signalling responses leading to lymphocyte integrin activation. Activated integrins bind to their ligands, such as the intercellular adhesion molecule-1 (ICAM-1), vascular cell adhesion molecule-1 (VCAM-1), and mucosal addressin cell adhesion molecule-1 (MAdCAM-1), expressed on the endothelium, resulting in the firm arrest of lymphocytes on the endothelium [5-7]. Following firm adhesion on the EC monolayer, lymphocytes eventually transmigrate into the tissue. Lymphocyte transendothelial migration can occur at the junction between apposing ECs (paracellular route) without disrupting the endothelial monolayer in a complex process known as trans-endothelial migration (TEM) or diapedesis involving the junctional adhesion molecules [8]. Alternatively, leukocytes can migrate across the EC body into the tissue known as the transcellular route [9]. Once across the endothelial barrier, migrating lymphocytes continue to move through the subendothelial matrix [8] and the extravascular tissue to the site of inflammation in response to chemotactic gradients [3]. Further details on the extravasation process can be found in a recent review by Nourshargh and colleagues [10].

A wide range of adhesion molecules and chemokines expressed on the ECs are required to bind to their counter receptors on the migrating lymphocytes, directing lymphocyte entry into the tissue [11]. The endothelium of different organs is characterized by preferential expression of combinations of these molecules, thus being endowed with the ability to selectively recruit distinct lymphocyte subsets. During priming, the local microenvironment and cellular interactions induce $\mathrm{T}$ lymphocytes to express a unique set of adhesion molecules and chemokine receptors (the 'homing' receptors) so that antigen-experienced $\mathrm{T}$ cells acquire the ability to interact with organ-specific ECs and migrate to distinct target tissues [12-15]. Given that recurrent infections are likely to affect the same organ, the acquisition of tissue tropism by memory $\mathrm{T}$ cells contributes to the effectiveness of recall responses. We here review the molecular interactions and mechanisms which underlie the ability of distinct memory $\mathrm{T}$ cell populations to migrate to different non-lymphoid sites where antigen is located.

\section{Naïve $T$ cell homing to secondary lymphoid organs (SLOs)}

Naïve and memory $\mathrm{T}$ cells display different surface molecules which define their functional properties and migratory patterns [16-19]. Naïve T cells have little or no ability to produce cytokines [20]. They recirculate from the blood, through secondary lymphoid organs (SLOs), into the lymphatic vessels and back to the blood [14, 21]. SLOs include peripheral lymph nodes (PLNs), spleen, gut-associated lymphoid tissue (GALT) including Peyer's patches (PPs), and bronchus-associated lymphoid tissue [22].

Homing of naïve $T$ cells to the PLNs requires the expression of CD62L and the chemokine receptor CCR7. CD62L binds to peripheral lymph node addressin (PNAd) expressed on the high endothelial venules (HEVs) of PLNs and mesenteric lymph nodes (MLNs) [23], while the 
chemokine receptor CCR7 binds to the chemokines CCL19 and CCL21 expressed by HEVs of the PLNs [24, 25]. CCL21 is also expressed in PPs [26]. Naïve T cells have also been shown to utilize CXCR4, which is the receptor for the chemokine stromal cell-derived factor 1 (SDF-1, CXCL12), to circulate through SLOs [27]. It has been shown that mineralocorticoid receptor signalling contributes to human naïve $\mathrm{T}$ cells migration to lymph nodes (LNs) by increasing CD62L, CCR7, and CXCR4 expression. Sleep-dependent release of endogenous aldosterone activates mineralocorticoid receptors on naïve $T$ cells. This leads to an increase in the expression of CCR7 and CD62L, as well as of CXCR4. Central memory T cells with lymph node-homing capacity were also affected. This could explain the beneficial effect of sleep on mounting an adaptive immune response [28]. Naive $T$ cells enter the LNs via HEVs, which are specialized postcapillary venules characterized by plump, cuboidal shapes and exclusively found in the SLOs [29, 30]. A recent study suggested that DCs sustain the entry of naive lymphocytes to LNs by modulating the phenotype of HEVs during homeostasis in adult mice. The effect of DCs on HEV is direct and requires lymphotoxin- $\beta$-receptor-dependent signalling. In the absence of DCs, HEV-mediated lymphocyte recruitment to LNs is inhibited [31].

CCR7 is also used by DCs to traffic from interstitial tissues into lymphatics and draining lymph nodes, in response to the chemokines CCL19 and CCL21. Kiermaier and colleagues showed that sialic acids on the surface of CCR7 recognize CCL21, regulating DCs trafficking to LNs. DCs deficient in polysialyltransferase ST8Sia IV, responsible for posttranslational addition of sialic acids to $\mathrm{N}$ - and/or O-linked glycans, fail to migrate in response to CCL21; however, their migration to CCL19 remains unchanged. Structure-function analysis also revealed that CCL21 exists in an auto-inhibited conformation, which is released upon interaction with polysialic acid addition to CCR7, allowing DCs sufficient in ST8Sia IV to respond to CCL21. DCs trafficking is abrogated in polysialyltransferase-deficient mice, manifesting as disturbed lymph node homeostasis and unresponsiveness to inflammatory stimuli [32].

Although previously thought not to require specific mechanisms for $\mathrm{T}$ cell recruitment, migration of naive $\mathrm{T}$ cells to the spleen has been recently shown to be facilitated by the angiotensin II (Ang II)/AT1 axis. Naïve T cells migrate to Ang II via the AT1 receptor. Importantly, a gradient of Ang II from peripheral blood to the spleen was measured. Higher levels of Ang II in the spleen induced upregulation of CD62L and CCR9 expression on $\mathrm{T}$ cells and production of CCL19 and CCL25 in the spleen, thus indirectly inducing their recruitment [33].
In humans, the majority of $\mathrm{T}$ cells entering the PPs are found to be naive $T$ cells. This process requires the interaction of integrin $\alpha_{4} \beta_{7}$ on T cells and MAdCAM- 1 on the mucosal vasculature $[26,34]$. Consistent with this observation, human naïve $\mathrm{T}$ cells constitutively express low levels of $\alpha_{4} \beta_{7}[35,36]$. Other studies subsequently showed that both CD62L and $\alpha_{4} \beta_{7}$ are required in a sequential and synergistic manner to mediate naïve $\mathrm{T}$ cell migration to the MLNs [37]. CD62L binds to the PNAd expressed on the MLNs, which induces the initial rolling and tethering of $\mathrm{T}$ cells during transendothelial migration; $\alpha_{4} \beta_{7}$ integrins subsequently bind to MAdCAM-1 and mediate firm adhesion and transmigration. T cell migration to the PPs is reduced by $55 \%$ in mice that are deficient for $\mathrm{CD} 62 \mathrm{~L}$; and mice lacking $\beta_{7}$ integrin expression have been found to display a $90 \%$ reduction in lymphocyte migration to the PPs [37]. Collectively, this evidence highlights the importance of both CD62L and $\alpha_{4} \beta_{7}$ in naïve T cell homing to the GALT.

A number of studies have revealed marked differences in dwelling times of $\mathrm{CD}^{+}$and $\mathrm{CD} 8^{+}$naïve $\mathrm{T}$ cells in $\mathrm{LNs}$ before egressing into lymph. $\mathrm{CD} 4^{+} \mathrm{T}$ cells home to $\mathrm{LNs}$ more efficiently, traverse LNs twice as quickly. In contrast, $\mathrm{CD} 8^{+} \mathrm{T}$ cells enter and leave the LNs more slowly. Cell-cell contacts have been suggested to determine how long $\mathrm{CD} 4^{+}$and $\mathrm{CD} 8^{+}$ $\mathrm{T}$ cell spend in LNs, specifically those made with DCs via major histocompatibility complex (MHC) molecules [38]. Expression of CCR7 and sphingosine-1-phosphate receptor 1 (S1PR1) has been shown to affect the time spent by T cells within LNs. CCR7 promotes retention, whereas S1PR1 expression is essential to overcome this retention signal and promote egress into the efferent lymph by interaction with its ligand sphingosine-1-phosphate (S1P) from the circulation [39-42]. CD69 is another major regulator of lymphocyte migration. CD69 directly binds S1PR1 receptor on the lymphocyte surface and mediates internalization of S1PR1, thus preventing lymphocyte egress [40, 41].

\section{Memory $\mathbf{T}$ cell homing to non-lymphoid tissue}

Naïve T cells sequestered in the SLOs interact with antigens presented by DCs [43], and undergo clonal expansion and differentiation into heterogeneous antigen experienced $\mathrm{T}$ cells. Recently activated $\mathrm{T}$ cells leave the SLOs via the efferent lymphatics, enter the blood circulation through the thoracic duct and travel to the inflamed tissues. Promotion of lymphocyte egress into lymph and blood is sustained by distinct sources of S1P [44]. Tregs have been shown to regulate effector $\mathrm{T}$ cells $\left(\mathrm{T}_{\mathrm{EFF}}\right)$ migration to nonlymphoid tissue by downregulating the expression of the S1PR1 [45]. S1PR1 has also been shown to inhibit the generation of Tregs while driving $\mathrm{T}$ helper 1 (Th1) development via signalling through the kinase mammalian target of 
rapamycin (mTOR) and antagonizing the function of transforming growth factor- $\beta$ (TGF- $\beta$ ) [46].

Primed T cells are a heterogeneous population consisting of short-lived $T_{E F F}$, long-lived central memory $T$ cells $\left(\mathrm{T}_{\mathrm{CM}}\right)$, long-lived effector memory $\mathrm{T}$ cells $\left(\mathrm{T}_{\mathrm{EM}}\right)$, and longlived tissue resident memory $\mathrm{T}$ cells $\left(\mathrm{T}_{\mathrm{RM}}\right)$. These cells are defined by their different phenotypes, functions and migratory patterns $[47,48]$. Short-lived $\mathrm{T}_{\mathrm{EFF}}$ represent the majority of recently activated $\mathrm{T}$ cells, and are eliminated at the end of primary immune responses $[19,49,50]$. $\mathrm{T}_{\mathrm{CM}}$ are able to proliferate rapidly during secondary immune responses [51]. $\mathrm{T}_{\mathrm{CM}}$ express $\mathrm{CD} 62 \mathrm{~L}$ and CCR7, and share migratory patterns with naive $\mathrm{T}$ cells; however, unlike naïve $\mathrm{T}$ cells they also express inflammatory chemokine receptors which enable them to enter sites of chronic inflammation [11]. For example, $\mathrm{T}_{\mathrm{CM}}$ preferentially accumulate and undergo homeostatic proliferation in the bone marrow [52, 53]. CXCR4 binding to SDF-1 play an essential role in $\mathrm{T}_{\mathrm{CM}}$ homing to the bone marrow [54]. CXCR4-deficient $\mathrm{T}_{\mathrm{CM}}$ exhibit defective homeostatic self-renewal, which correlates with impaired homing to the bone marrow. Upon rechallenge, however, CXCR4-deficient $\mathrm{T}_{\mathrm{CM}}$ can proliferate and differentiate efficiently while self-renewing [55]. In contrast, both long-lived $\mathrm{T}_{\mathrm{EM}}$ and short-lived $\mathrm{T}_{\mathrm{EFF}}$ lack the expression of CD62L and CCR7. They use instead tissuespecific integrin and chemokine receptors to preferentially migrate to non-lymphoid tissues $[48,56]$.

Primed T cells have different degree of access to distinct tissues at steady state. Based on T cell recirculation, tissues of the body can be characterized into three classes. First, 'permissive tissues', such as lung parenchyma, liver, kidney, spleen and adipose tissue, are readily accessible by $\mathrm{T}_{\mathrm{EFF}}$ without the need for any local inflammation or antigen $[57,58]$. Second, 'restrictive tissues', includes skin epidermis, lung airways, vaginal epithelial layer, and salivary glands, are inaccessible by $\mathrm{T}_{\mathrm{EFF}}$ at steady state. These tissues require local inflammation leading to production of inflammatory cytokines and chemokines to render ECs permissive to $\mathrm{T}_{\mathrm{EFF}}$ migration [59-61]. Third, 'effector permissive tissues', including the gut, brain, and peritoneal cavity, are accessible by $\mathrm{T}_{\mathrm{EFF}}$ during the effector phase when homing receptors are broadly expressed, but not by $\mathrm{T}_{\mathrm{EM}}$ and $\mathrm{T}_{\mathrm{CM}}[57,62,63]$.

Upon reaching the site of infection, memory $\mathrm{T}$ cells mount immune response, leading to pathogen clearance. Th cells regulate diverse and appropriate cellular and humoral responses to a wide range of pathogens/antigens by differentiating into a variety of subsets-Th1, Th2, Th9, Th17 and inducible Tregs (iTregs)—defined by their distinct profile of transcription factor, cytokine, function and homing receptors expression. There are various mechanisms to ensure the stability of different $\mathrm{T}$ cell subsets, such as expression of genes turned on by transcription factors, repression of genes conferring alternative fates, epigenetic modifications and microRNA expression. However, there are many examples of flexible expression of cytokines, transcription factors and homing receptors by established Th cells [64-66]. For example, Th17 cells can simultaneously produce IL-17 and IFN- $\gamma$ [67], or IL-17 and IL-4 [68].

Migration of Th cells to peripheral sites of inflammation is essential for execution of their effector function. Different Th cell subsets may use different adhesion molecules and chemokine receptors to traffic during inflammation. It has been reported that binding of $\mathrm{T}$ cell immunoglobulin and mucin domain 1 (TIM-1) to P-selectin mediates tethering and rolling of Th1 and Th17, but not Th2 and Tregs [69]. The chemokine receptors CXCR3, CXCR6 and CCR5 are preferentially expressed on Th1 cells [70, 71], whereas CCR3, CCR4 and CCR8, along with the prostaglandin $\mathrm{D}_{2}$ receptor CRTH2 (chemoattractant receptor homologous molecule on Th2 cells), are expressed on Th2 cells [7173]. More recently, CCR6 and CCR 4 have been shown to characterize the Th17 subset, although there is also evidence that Th17 cells may express CCR2 and CCR9 [7477]. In addition, the same Th cell lineage may use different receptors to migrate to inflammation sites depending on disease models. For example, Th9 cells express functional chemokine receptors CCR3, CCR6, and CXCR3 for the recruitment to disparate inflammatory sites; however, during allergic inflammation, Th9 cells preferentially use CCR3 and CCR6, not CXCR3; finally, Th9 homing to the central nervous system (CNS) during experimental autoimmune encephalomyelitis (EAE) involves CXCR3 and CCR6 but not CCR3 [78].

At the end of immune reaction, the tissue microenvironment provides instructive signals for some $\mathrm{T}_{\mathrm{EFF}}$ to express molecules that enable long-term residency and survival to become $T_{R M}$. $T_{R M}$ does not readily circulate and comprises a major component of lymphocyte populations in diverse peripheral tissue sites, including mucosal tissues, barrier surfaces, and other lymphoid and nonlymphoid sites in humans and mice [79-84]. Functionally, $\mathrm{T}_{\mathrm{RM}}$ provide an immediate in situ immune response to infection due to their localization in barrier tissues, and also contain relatively high frequencies of $\mathrm{T}$ cell clones specific for pathogens as $\mathrm{T}_{\mathrm{RM}}$ are likely derived from clonally expanded $\mathrm{T}_{\mathrm{EFF}}$ responding to an infection [85-87]. Phenotypically, $\mathrm{T}_{\mathrm{RM}}$ are distinguished from circulating $\mathrm{T}_{\mathrm{EM}}$ based on upregulated expression of CD69 by both CD4 and CD8 $\mathrm{T}_{\mathrm{RM}}$, and CD103 by CD8 $\mathrm{T}_{\mathrm{RM}}$ [83, 84]. E-cadherin, the ligand for CD103, is expressed on epithelial cells. It is possible that interactions between E-cadherin and $\mathrm{CD} 103$ contribute to maintaining $\mathrm{T}_{\mathrm{RM}}$ in peripheral tissues. TGF- $\beta$, a cytokine secreted by various skin and mucosal epithelial cells $[88,89]$, stimulates CD8 T cells to 
express the integrin CD103 [90]. Antigen-stimulated CD69 expression by $\mathrm{T}_{\mathrm{RM}}$ inhibit the egress receptor S1PR1 by binding to the transmembrane region of S1PR1 and promotes its degradation [91]. S1PR1 responds to concentrations of S1P, which is scarce in the tissue but highly abundant in blood and lymph [42]. S1PR1 expression requires transcription factor Krüppel-like factor 2 (KLF2), which is downregulated once $\mathrm{T}_{\mathrm{EM}}$ seed the peripheral tissue [92]. Downregulation of KLF2 also decreases the expression of CCR7, which is another egress receptor on tissue lymphocytes required for their migration into the draining LNs [93, 94].

$\mathrm{T}_{\mathrm{RM}}$ have been reported to survive in memory lymphocyte clusters (MLCs), which are formed within the parenchyma of the tissue after a local infection or immunization. MLCs contain CD4 $\mathrm{T}_{\mathrm{RM}}$ and CD8 $\mathrm{T}_{\mathrm{RM}}$ as well as antigen presenting cells (APCs) that hold the cluster together [95]. MLCs appear to contain a depot of low levels of antigenic peptides that provide antigenic stimuli for $\mathrm{T}_{\mathrm{RM}}$ retention $[63,96]$. How $\mathrm{T}_{\mathrm{RM}}$ are released from MLCs to migrate toward the infected cells remains to be determined.

Like other memory $\mathrm{T}$ cells, $\mathrm{T}_{\mathrm{RM}}$ survival depends on the delivery of signals such as those mediated by IL-15 [93]. Recently Adachi and colleagues demonstrated that the epidermotropism of $\mathrm{T}_{\mathrm{RM}}$ is supported by the hair folliclederived cytokines IL-15 and IL-7. They showed that skin CD4 and CD8 $T_{R M}$ reside predominantly within the hair follicle epithelium of the unperturbed epidermis. Hair follicle expression of IL-15 was required for $\mathrm{CD} 8 \mathrm{~T}_{\mathrm{RM}}$ cells, and IL-7 for both CD8 and CD4 $\mathrm{T}_{\mathrm{RM}}$ to exert epidermotropism. A lack hair follicle-derived cytokines led to the failure of both CD4 and CD8 $\mathrm{T}_{\mathrm{RM}}$ to persist in the skin, leading to impaired hapten-induced contact hypersensitivity responses [97]. A recent study by Mackay and colleagues demonstrated that the T-box transcription factors (TFs) Eomes and T-bet combine to control the expression of TGF- $\beta$ and IL-15, which are pivotal for $\mathrm{CD}^{+} \mathrm{CD} 103^{+} \mathrm{T}_{\mathrm{RM}}$ development and survival. They showed that extinguishment of Eomes was necessary for $\mathrm{CD}^{+} \mathrm{CD} 103^{+} \mathrm{T}_{\mathrm{RM}}$ development, and residual $\mathrm{T}$-bet expression maintained cell surface $\mathrm{IL}-15$ receptor $\beta$-chain (CD122) expression necessary for IL-15-induced survival signals [98].

Another study by Hondowicz and colleagues revealed that interleukin-2 (IL-2) signaling was required for the formation of lung-resident memory Th2 cells, drivers of lung allergic responses. They found that significantly greater numbers of $\mathrm{CD} 25$-sufficient than $\mathrm{CD} 25$-deficient allergen-specific Th2 cells were found in the lungs after intranasal administration of allergen. They further showed that IL-2 regulates a broad migrational program of lymphocyte retention and migration, regulating the early residency of allergen-specific $\mathrm{CD} 4^{+} \mathrm{T}$ cells in the lung [99].

Memory $\mathrm{T}$ cells can also leave parenchymal tissue and return to the circulation. The mechanisms leading to the release of memory $\mathrm{T}$ cells from parenchymal tissue into the circulation have been only partially characterised. The chemokine receptor CCR7 has been proposed to guide T cell exit from peripheral tissues and entry into afferent lymphatics [100]. However, a conflicting report suggests that CCR7 plays a discernible role in the trafficking of memory $\mathrm{CD}^{+}{ }^{+} \mathrm{T}$ cells to the $\mathrm{LN}$, either directly from the blood or from peripheral tissues such a skin [62]. A study has reported that murine $\mathrm{T}_{\mathrm{EM}}$ and $\mathrm{T}_{\mathrm{EFF}}$ can also be recruited to the reactive LNs in a CCR7-independent pathway via the chemokine receptor CXCR3 to kill antigen-presenting DCs thus preventing excessive $\mathrm{T}$ cell stimulation [101]. CXCR3 is upregulated on both Th1 and $\mathrm{CD}^{+} \mathrm{T}$ cells upon activation and maintained on these $\mathrm{T}$ cell subsets throughout the effector and memory phase [102].

After exit from the tissue, memory $\mathrm{T}$ cells may continue recirculating in the blood or localize in 'reservoir' niches: memory $\mathrm{T}$ cells tend to preferentially reside in the spleen in chronic inflammation with antigen persistence; alternatively they localize to the bone marrow if the infectious/inflammatory process is acute but transient [48, 103, 104].

\section{Memory $\mathbf{T}$ cell homing to the skin}

Effector/memory $\mathrm{T}$ cells trafficking to skin depends on the expression of cutaneous lymphocyte-associated antigen (CLA), CCR4 and CCR10 [105]. It has been demonstrated that human memory $\mathrm{T}$ cells require the expression of CLA to traffic to the skin by binding to E-selectin, which is constitutively expressed at a low level by ECs in the skin and is upregulated upon cutaneous inflammation [106, 107]. Human skin-infiltrating lymphocytes also express CCR4, the chemokine receptor for CCL17 (also known as the thymus and activation-regulated chemokine, TARC) displayed on the skin post-capillary venules [108]. CCL17 is produced by dendritic cells (DC), endothelial cells, keratinocytes and fibroblasts [109]. Further studies revealed that CCL27 (the cutaneous $\mathrm{T}$ cell-attracting chemokine, CTACK), expressed by skin keratinocytes, also contributes to memory $\mathrm{T}$ cells recruitment to the skin by binding to its receptor CCR10 [110]. Other key molecules participating in memory $\mathrm{T}$ cell homing to the skin include the integrin $\alpha_{4} \beta_{1}$ (VLA-4), which binds to VCAM-1 expressed by the endothelium [36]. T cells expressing high levels of $\alpha_{4} \beta_{1}$ preferentially home to the systemic nonmucosal sites including the skin, CNS and bone marrow [111]. 
The requirement and redundancy of individual chemokine receptors in $\mathrm{T}$ cell homing to the skin is still controversial. Marked reduction of dinitrofluorobenzeneinduced allergic contact dermatitis (ACD) was observed following neutralization of CCL27-CCR10 interactions in Balb/c mice [112] and in CCL17-deficient mice [113]. However, Reiss and colleagues reported that simultaneous inhibition of CCR4 and CCR10 was required to block lymphocyte recruitment to reduce dinitrofluorobenzeneinduced ACD [108]. Similarly, Mirshahpanah et al. demonstrated that only combination therapy of neutralizing antibodies to CCL17, CCL27 and CCL22 resulted in oedema inhibition using three different ACD models [114]. Differences in the relative contribution requirements for individual chemokine receptors in T cell homing to the skin may be in part explained by different genetic background and experimental models used in these studies.

The skin tissue microenvironment provides instructive signals for some recruited effector/memory $\mathrm{T}$ cells to express molecules that enable long-term residency and survival to become skin $\mathrm{T}_{\mathrm{RM}}$. It has recently emerged that skin $\mathrm{T}_{\mathrm{RM}}$ are crucial for protection not only against the antigenic pathogen but also against antigenically unrelated viruses and bacteria. Activated skin $\mathrm{T}_{\mathrm{RM}}$ can profoundly alter the local tissue environment by inducing a number of broadly active antiviral and antibacterial genes [115]. The mouse skin has been shown to harbour the so-called dendritic epidermal T cells (DETCs), a unique, highly specialized lymphocyte subset characterized by its dendritic shape [116-118]. DETCs participate in various activities including wound healing and epidermal barrier function [117-119]. Embryonic trafficking of DETCs to the epidermal skin requires $G$ protein-coupled receptor 15 (GPR15) [120]. DETCs in GPR15 ${ }^{-1-}$ mice remain low at birth, but later participation of vascular E-selectin, CCR4 [105] and CCR10 [121] allows DETCs to reach near normal levels in adult skin.

\section{Memory $\mathbf{T}$ cell homing to the intestine}

Effector and memory $\mathrm{T}$ cells require the interaction of integrin $\alpha_{4} \beta_{7}$ and MAdCAM-1 to migrate to the effector site of the gut mucosa-the lamina propria (LP) [34, 122]. MAdCAM-1 is constitutively expressed on the postcapillary venules of intestinal LP and MLNs, the HEVs of the PPs [12] and the endothelial venules of both small intestine and colon [123]. The ability of $\alpha_{4} \beta_{7}$ expressing cells to bind to MAdCAM-1 is influenced by the level of $\alpha_{4} \beta_{7}$ expression and its functional state [35]. Human peripheral blood $\mathrm{CD}^{+}{ }^{+}, \mathrm{CD}^{+}{ }^{+} \mathrm{T}$ cells have heterogeneous expression of $\alpha_{4} \beta_{7}[35,124]$. The level of $\alpha_{4} \beta_{7}$ expression is much higher on memory cells than naïve cells [35, 36]. Other than its crucial function in mediating lymphocyte homing to the gut, studies in mice have also revealed that $\alpha_{4} \beta_{7}$ plays a critical role in the formation of GALT [125]. Mice lacking MAdCAM-1 have a disordered architecture in their PPs and MLNs [126]. $\alpha_{4} \beta_{7}$-dependent gut trafficking is essential but not sufficient to induce intestinal inflammation. Studies demonstrated that differential ability for $\alpha_{4} \beta_{7}^{+}$ $\mathrm{T}$ cells to become colitogenic may be linked to their antigen reactivity, and the reactivity was enhanced by the presence of $\gamma \delta$ T cells [127].

In addition to its role in adaptive immunity, $\alpha_{4} \beta_{7}$ is also required for innate immune cells to migrate to intestine. Villablanca et al. showed that $\beta_{7}$ integrins are required for bone marrow progenitors to reconstitute the small intestine mononuclear phagocyte compartment including retinoic acid (RA)-producing DCs in mLNs. Lack of $\beta_{7}$ integrins in the innate immune compartment markedly accelerated $\mathrm{T}$ cell-mediated colitis due to decreased ability to induce Tregs and IL-10-producing T cells [128].

Interestingly, interaction of $\alpha_{4} \beta_{7}$ with MAdCAM- 1 has been proposed to contribute to immune tolerance in other organs by selective sequestration of pro-inflammatory $\mathrm{T}$ cells in the intestine. Berer and colleagues found that the pro-inflammatory, myelin-reactive Th17 cells were enriched in the intestine of EAE-susceptible mice, but failed to reach the peripheral immune organs, resulting in the absence of spontaneous EAE. The release of intestine-sequestered Th17 cells via blocking of $\alpha_{4} \beta_{7}$-mediated adhesion to the intestine by treating mice with $\alpha_{4} \beta_{7^{-}}$ specific monoclonal antibodies worsened EAE [129]. Similarly, treatment of EAE mice with IL-4 increased retinaldehyde dehydrogenase (RALDH) activity in DCs, which enhanced RA production, induced expression of $\alpha_{4} \beta_{7}$ and CCR9 on $\mathrm{CD}^{+} \mathrm{T}$ cells and deviated their migration from the dLNs-CNS route to the mLNs-gut thus improving EAE outcome without overt colitis [130].

Upon arrival in the intestinal LP, some $\mathrm{T}$ cells further migrate to the gut epithelium to become intraepithelial lymphocytes (IELs) in a process dependent on the interaction of chemokine receptor CCR9 and its ligand CCL25 [131-133]. In mice, the CCR9-CCL25 axis has been shown to play a key role in the homing of antigen-specific $\mathrm{CD}^{+} \mathrm{T}$ lymphocytes to the small intestine LP [134], but less so for $\mathrm{CD}^{+}{ }^{+}$effector T cells [135]. CCR9 is expressed by thymic T cells, $\alpha_{4} \beta_{7}^{+}$LP T cells and IELs in the small intestine in humans and mice [132, 133, 136]. CCL25 is expressed in the thymus and the small intestinal glands and crypts [137]. CCL25 has also been found to be expressed by gut endothelium and epithelial cells in mice [138]. Within the murine small intestine, CCL25 is found at a higher concentration at the proximal segments compared to the distal segments [138]. In humans, CCL25 is abundantly expressed in various regions of the small intestine (jejunum and the ileum), but not in the colon or the caecum [132, 
139]. In line with these observations, CCR9-CCL25 interactions are required for memory $\mathrm{T}$ cell homing to the small intestine, while they do not appear to be essential for $\mathrm{T}$ cell migration to the colon in humans or mice $[132,140]$. Blockade of CCL25 had no effect on murine T cell adhesion in the colon in both non-inflamed and inflamed conditions, while it significantly inhibited $\mathrm{T}$ cell adhesion in the small intestine [137, 141]. Consistent with these findings, over $90 \%$ of both $\mathrm{CD}^{+}$and $\mathrm{CD}^{+}{ }^{+} \mathrm{T}$ cells isolated from the human small intestine express CCR9, in contrast only $25 \%$ of colonic $\mathrm{CD}^{+}$and $\mathrm{CD}^{+}{ }^{+} \mathrm{T}$ cells are CCR9 positive $[132,139]$. Only a small percentage of total circulating $\mathrm{CD}^{+}{ }^{+}$and $\mathrm{CD} 8^{+}$T cells co-express $\alpha_{4} \beta_{7}$ and CCR9 in human peripheral blood, further enforcing the concept that $\mathrm{T}$ cell homing to the small and large intestine may not be achieved via the same pathways [133]. Instead, CCL25 may be responsible for compartmentalizing the mucosal immune responses within the gut $[132,136]$.

Optimal expression of $\alpha_{4} \beta_{7}$ and CCR9, particularly by $\mathrm{CD}^{+} \mathrm{T}$ cells, has been found to be regulated by basic leucine zipper transcription factor (BATF), an AP-1 protein family factor. Wand and colleagues showed that BATF is required for $\mathrm{CD}^{+} \mathrm{T}$ cells to up-regulate the gut-homing receptors in response to RA upon antigen priming and migrate into and populate the intestine. BATF deficient $\mathrm{CD}^{+}{ }^{+} \mathrm{T}$ cells failed to up-regulate the expression of CCR9 and $\alpha_{4} \beta_{7}$ to wild type levels in response to RA, and are ineffective in migration into the intestine [142].

The concept that immune surveillance of the intestine is dependent on a large cohort of recirculating $\alpha_{4} \beta_{7}^{\text {high }}$ memory $\mathrm{T}$ cells has recently been challenged by a seminal study showing that the expression of $\alpha_{4} \beta_{7}$ is lost by the majority of circulating memory $\mathrm{T}$ cells-including those activated in the GALT - despite the maintenance of protective immunity [62]. In addition, loss of $\alpha_{4} \beta_{7}$ and CCR9mediated interactions by genetic deletion does not prevent gut immunity from taking place [140, 143], suggesting the existence of redundant mechanisms of $\mathrm{T}$ cell migration to the intestine.

A few other molecules also play a non-redundant role in intestinal homeostasis. Soluble lymphotoxin $\alpha$ produced by $\mathrm{ROR} \gamma \mathrm{t}^{+}$innate lymphoid cells induce GALT development. Mice deficient in soluble lymphotoxin $\alpha$ lacked GALT such as PPs, abrogated IgA production in the gut and altered microbiota composition via regulation of $\mathrm{T}$ cell homing to the gut [144] as $\mathrm{T}$ cell-dependent regulation of IgA production takes place mainly in PPs and requires the formation of germinal centres and the interaction of B cells with follicular Th cells [145]. Additionally, GPR18 has been shown to promote the maintenance of small intestinal IELs. Mice lacking this orphan receptor have reduced numbers of the CD $8 \alpha \alpha, C D 8 \alpha \beta$, and $\gamma \delta$ T IELs [146]. GPR15 was also involved in the homing of $\mathrm{T}$ cells, particularly Forkhead Box P3 (FoxP3) ${ }^{+}$Tregs, to the large intestine LP. GPR15-deficient mice were prone to develop more severe large intestine inflammation. Unlike $\alpha_{4} \beta_{7}$ and CCR9, GPR15 expression was not modulated by RA, but by gut microbiota and TGF- $\beta-1$ [147].

\section{Memory T cell homing to other mucosal sites}

Unlike well-defined $\mathrm{T}$ cell homing to the gut, the molecular pathways regulating the migration of $\mathrm{T}$ cells to other mucosal sites are not fully defined. A few molecular mechanisms have been suggested to contribute to $\mathrm{T}$ cells homing to the airway. Danilova and colleagues suggested that CCR3 is involved in the steady-state trafficking of $\mathrm{CD}^{+}{ }^{+} \mathrm{T}$ cells to the human upper airway mucosa [148], as CCR3 ligand CCL28 is preferentially expressed in various mucosal tissues of the upper aerodigestive tract $[149,150]$. Another study proposed that CCR4 contributes to T cell lung homing imprinting. It was found that lung DCs induce the expression of CCR4 on T cells. Lung DCs-activated T cells traffic more efficiently into the lung and protect against influenza more effectively compared with $\mathrm{T}$ cells activated by DCs from other tissues [151]. Lim and colleagues suggested that CXCR4 plays a role in $\mathrm{CD}^{+} \mathrm{T}$ cell migration to airway tissues. They demonstrated that early recruited neutrophils into influenza-infected trachea deposit long-lasting SDF-1-containing trails, which provide both chemotactic and haptotactic cues for efficient CXCR4 expressing $\mathrm{CD} 8^{+} \mathrm{T}$ cell migration and effector functions in influenza-infected tissues [152].

Molecular mechanisms regulating the migration of $\mathrm{T}$ cells to the female genital tract have also been studied. Shannon and colleagues showed that asymptomatic herpes simplex virus (HSV)-2 infection was associated with systemic $\mathrm{T}$ cell immune activation and a dramatic increase in their expression of the mucosal homing $\alpha_{4} \beta_{7}$ and CCR5, which directly correlated with the number of activated and CCR5-expressing human immunodeficiency virus (HIV)susceptible $\mathrm{CD}^{+}{ }^{+} \mathrm{T}$ cell subsets in the cervix [153]. This may explain why asymptomatic HSV-2 infection is associated with a threefold increase in HIV acquisition risk [154]. In contrast, another study showed that integrin $\alpha_{4} \beta_{1}$, but not $\alpha_{4} \beta_{7}$, contributes to $\mathrm{CD} 4^{+} \mathrm{T}$ cell trafficking to the uterus. It was demonstrated that $C$. trachomatis infection of the upper genital tract results in recruitment of chlamydiaspecific $\mathrm{CD}^{+} \mathrm{T}$ cells robustly expressing the integrin $\alpha_{4} \beta_{1}$. Blocking or deleting $\alpha_{4} \beta_{1}$, but not $\alpha_{4} \beta_{7}$, on pathogenspecific $\mathrm{CD}^{+} \mathrm{T}$ cells results in the impairment of trafficking to the uterus and high bacterial load [155]. Unique challenges posed by HIV or other sexually transmitted infections such as HSV require further research on memory lymphocytes generation against HIV or HSV with mucosal tissue tropism to design effective $\mathrm{T}$ cell-based vaccines. 


\section{Memory $\mathbf{T}$ cell homing to the liver and the heart}

$\mathrm{T}$ cell homing to the liver has received much attention in recent years, and a number of molecular mediators of $\mathrm{T}$ cell localization to hepatic tissue have been identified. Studies in experimental models of liver inflammation have indicated that Th1 cells may use VLA-4 to traffic to liver, whilst Th2 cells may use a presently uncharacterized ligand for endothelial vascular adhesion protein-1 (VAP-1), which is constitutively expressed on hepatic venules and liver sinusoids [156]. Other reports suggested the involvement of the hyaluronan receptor CD44 in lymphocyte homing to liver [157]. CCR5 has also been suggested as a mediator of recruitment of $\mathrm{T}$ cells in the liver during acute inflammation as well as during numerous autoimmune diseases, including multiple sclerosis, rheumatoid arthritis and type 1 diabetes [158]. First, CCR5 is preferentially expressed on Th1 cells, and Th1 cell-mediated immune responses play a critical role in hepatocyte damage induced by autoimmunity and viral infections [159, 160]. Second, it was found that some CCR5 antagonists might induce profound hepatotoxicity during clinical trials [158]. Third, CCR5 blockade/deficiency is associated with significant increase in tissue levels of the CCR5 ligand CCL5 [161, 162], which can promote enhanced influx of leukocytes (including $\mathrm{T}$ cells) by binding to its alternative receptor, CCR1, expressed on circulating leukocytes [161, 163].

Besides homing to the skin and liver, it has been challenging to identify unique tissue-homing signatures to other solid organs including the heart. It has been shown previously that the chemokine receptors CCR4 [164] and CXCR3 [165] are contributing to $\mathrm{T}$ cell accumulation during heart transplant rejection. Recently we have uncovered a molecular mechanism of induction of $\mathrm{T}$ cell cardiotropism. We found that engagement of the hepatocyte growth factor (HGF) receptor c-Met by heartproduced HGF during priming in the LNs instructs $\mathrm{T}$ cell cardiotropism, which was associated with a specialized homing "signature" $\left(\mathrm{c}-\mathrm{Met}^{+} \mathrm{CCR} 4^{+} \mathrm{CXCR} 3^{+}\right)$. HGF is expressed by healthy heart tissue and transported to local draining LNs. Inside heart draining LNs, HGF bind to c-Met on naive $\mathrm{T}$ cells, inducing higher expression of c-Met itself and of the chemokine receptors CCR4 and CXCR3. C-Met triggering was sufficient to support cardiotropic $\mathrm{T}$ cell recirculation, while $\mathrm{CCR} 4$ and CXCR3 sustained recruitment during heart inflammation. In steady state conditions, engagement of cMet induces autocrine release of beta chemokines, which favour $\mathrm{T}$ cell recruitment via their receptor CCR5. Under inflammatory conditions, cardiac tissue releases higher levels of the HGF and chemokines CXCL10 and CCL4, which facilitate HGF-primed $\mathrm{T}$ cells recruitment to the heart [166].

\section{Mechanisms of homing receptor acquisition}

The ability of local microenvironment to imprint $\mathrm{T}$ lymphocytes with a specific set of homing receptors has long been recognized. Tissue-associated DCs appear to be capable of imprinting the tropism of a $\mathrm{T}$ cell during the priming phase. It was first demonstrated in mice that only DCs isolated from the MLNs and PPs preferentially upregulated gut-homing receptors $\alpha_{4} \beta_{7}$ and CCR9 expression when activating naïve T cells $[134,167,168]$. In contrast, $\mathrm{T}$ cells activated in the cutaneous secondary lymphoid tissue expressed skin-homing receptors such as P-selectin glycoprotein ligand-1 (PSGL-1; CD162) [168, 169]. The mutually exclusive sets of skin and gut-homing receptors expressed by $\mathrm{T}$ cells commit them to either destination [36, 133].

More recent studies have shed light on the molecular mechanisms of 'local' imprinting. While tissue-associated DCs appear to be capable of imprinting the tropism of a T cell during the priming phase, additional signals within the tissue microenvironment may be required to imprint and maintain a particular homing program. A study by Iwata and colleagues highlighted the key role of the vitamin A (VA) metabolite RA in the imprinting of gut homing specificity on T cells [170]. VA enters the body exclusively through diet [171], absorbed and processed primarily in the small intestine [172]. VA is inactive and requires enzymatic processing to become activated [173]. It is first converted to retinal catalysed by ubiquitous alcohol dehydrogenases (ADH), and then to RA catalysed by cell specific RALDH [170, 174-176]. DCs in GALT express RALDH, which metabolise VA to RA $[170,171]$. RA along with antigens is presented by DCs to naïve T cells during priming. RA binds to its receptors-RAR and RXR expressed on naïve $T$ cells, which then up-regulate the expression of $\alpha_{4} \beta_{7}$ and CCR9 [170, 171, 177-180]. $\mathrm{CD} 103^{+}$DCs express higher levels of enzymes required for VA metabolism compared to $\mathrm{CD}_{103^{-}} \mathrm{DCs}$, represent the major migratory DC population in the intestinal LP and are believed to be most effective at generating $\alpha_{4} \beta_{7}^{+}$ $\mathrm{CCR}^{+} \mathrm{CD}^{+}{ }^{+} \mathrm{T}$ cells compared to DCs from MLNs or PPs [181]. However, The MLNs are believed to serve as the primary site where imprinting of gut homing specificity occurs as antigen-loaded DCs are carried into the MLNs via draining lymphatics [182-186].

DCs can also internalize exogenous RA produced by other cells in the gut such as LP macrophages [176], MLN stromal cells [187] and gut epithelial cells [188]. However, the contribution of RA from sources other than DCs towards the imprinting process is not fully established [189]. RA can also be produced by other DC populations, particularly in DCs located at the environmental interfaces, such as the skin, the lungs, and the corresponding draining 
LNs [190, 191]. Compared to DCs from GALT, DCs from the environmental interfaces are shown to be less effective at converting VA to RA, and are therefore less effective at inducing $\alpha_{4} \beta_{7}$ and CCR9 expression on T cells [170].

In addition to the role of producing and presenting RA to $\mathrm{T}$ cells, DCs also express the RA receptors and are able to respond directly to RA [192]. RA can modulate monocytederived DCs towards a mucosal-type DCs, which produce IL6 and TGF- $\beta$ and has capacity to induce gut-homing receptors on T cells [193]. RA can also influence the migratory properties of DCs. RA induces expression of the matrix metalloproteinases (MMP)-9 and MMP-14 [194, 195]. MMP9 and MMP-14 are involved in DC migration [196, 197]. RA promotes the migration of DCs in vivo toward draining LNs in a murine model of cancer [194]. Similar mechanisms involving VA metabolism are also used to instruct Tregs and B cells to become gut-tropic [180, 198-200].

Apart from inducing a gut-homing phenotype, RA also prevents the upregulation of skin-homing receptors by $\mathrm{T}$ cells [170]. It has been suggested that the acquisition of a skin-homing phenotype might be the default pathway for $\mathrm{T}$ cell activation in the absence of RA or when RAR signalling is blocked [201]. For example, a distinct inflammatory Th2 with homing receptors for skin and inflammatory sites was induced by DCs from MLNs in VA-deficient mice. The MLN-DC subset from VA-sufficient mice induced a similar $\mathrm{T}$ cell subset with homing receptors for skin and inflammatory sites in the presence of RAR antagonists. RA inhibited this induction [202].

Like the role of VA in the gut-homing imprinting, vitamin $\mathrm{D}_{3}$ has been implicated in the induction of a skinhoming phenotype in T cells. Skin-resident DCs have been shown to process vitamin $\mathrm{D}_{3}$, the inactive pro-hormone naturally generated in the skin by exposure to the sun, to $1,25(\mathrm{OH})(2) \mathrm{D}(3)$, the active form of vitamin $\mathrm{D}_{3}$. $1,25(\mathrm{OH})(2) \mathrm{D}(3)$ signals have been shown to induce CCR10 expression, which promote $\mathrm{T}$ cell trafficking to and/or retention in the skin epidermis via binding to its ligand CCL27 secreted by keratinocytes [173]. In contrast, $1,25(\mathrm{OH})(2) \mathrm{D}(3)$ suppresses the expression of the guthoming receptors $\alpha_{4} \beta_{7}$ and CCR9. Skin stromal cellderived prostaglandin E2 can also decrease gut-homing CCR9 expression upon $\mathrm{T}$ cell priming via inhibiting RALDH expression in mouse and human DCs. It was found that prostaglandin E2 stimulated the expression of the inducible cyclic AMP early repressor, which appears to directly inhibit RALDH expression in DCs [203].

Recent findings have provided strong evidence that soluble factors produced in selected tissues and drained in the local lymphatic stations contribute to the topographic imprinting of $\mathrm{T}$ cells during activation. It is known that tissue-derived small molecules can be directly delivered to draining LNs by anatomically defined conduits [204].
Some of these molecules are produced in a tissue-specific manner and can therefore define the topographic identity of the tissue where they are generated and possibly contribute to $\mathrm{T}$ cell homing imprinting. For example, skin-derived soluble factors have been shown to induce the skin homing receptor CCR8 in T cells [205]. We have reported recently that HGF produced by the myocardium is transported to the heart-draining LN either passively or bound to DCs [166]. Binding of HGF to its receptor c-Met on $\mathrm{T}$ cells induce intracellular signalling cascade involving Akt and STAT3 engagement, leading to increased expression of CCR4 and CXCR3 and secretion of several chemokines, including CCL3, CCL4, CCL5, CCL17, and CCL22. This mechanism represents an autocrine loop, by which $\mathrm{T}$ cells-once primed by $\mathrm{HGF}$ - stimulate both receptors and their ligands to re-direct $\mathrm{T}$ cells to heart tissue.

A summary of the homing receptors used by memory $\mathrm{T}$ cells to migrate to different tissues is provided in Fig. 1.

\section{T cell receptor: the ultimate addressin?}

Primed T cells must patrol very large areas to locate antigen-rich tissue to exert their function. Together with the acquisition of homing receptors during activation and differentiation, additional antigen-driven mechanisms have been proposed to orchestrate the targeted delivery of memory $\mathrm{T}$ cells to antigen-rich tissues. Several mechanisms could contribute to the accumulation of antigenspecific $\mathrm{T}$ cells at antigen-bearing sites: (a) a direct effect of antigen recognition on the recruitment of T cells; (b) the retention of antigen-specific $\mathrm{T}$ cells; (c) local proliferation of antigen-specific cells.

$\mathrm{T}$ cell receptor (TCR) recognition of antigen/MHC complexes presented by the endothelium has been reported both in vitro and in vivo to contribute directly to the recruitment of antigen-specific $\mathrm{T}$ cells. In vitro, cognate recognition of B7-deficient human and murine ECs was shown to enhance $\mathrm{T}$ cell trans-endothelial migration without inducing unresponsiveness [206-208]. In vivo, antigen presentation by the endothelium has also been shown to sustain the recruitment of specific $\mathrm{T}$ cells to antigenic sites. For instance, islet-specific homing by insulin-specific $\mathrm{CD}^{+} \mathrm{T}$ cells was abrogated in mice lacking MHC class I (MHC I) expression, or in mice displaying impaired insulin peptide presentation by local endothelium due to lack of insulin secretion [209]. Similarly, up-regulation of male antigen HY presentation by local vessels led to peritoneal recruitment of $\mathrm{HY}$ specific $\mathrm{CD}^{+}$lymphocytes $\mathrm{T}$ cells in male, but not female mice [210]. Indirect evidence implicating the requirement of MHC I molecule upregulation for $\mathrm{T}$ cell localization to antigen-rich non-lymphoid tissue was first provided by studies showing that homing of insulinspecific $\mathrm{CD}^{+} \mathrm{T}$ cells to the islets during the onset of 


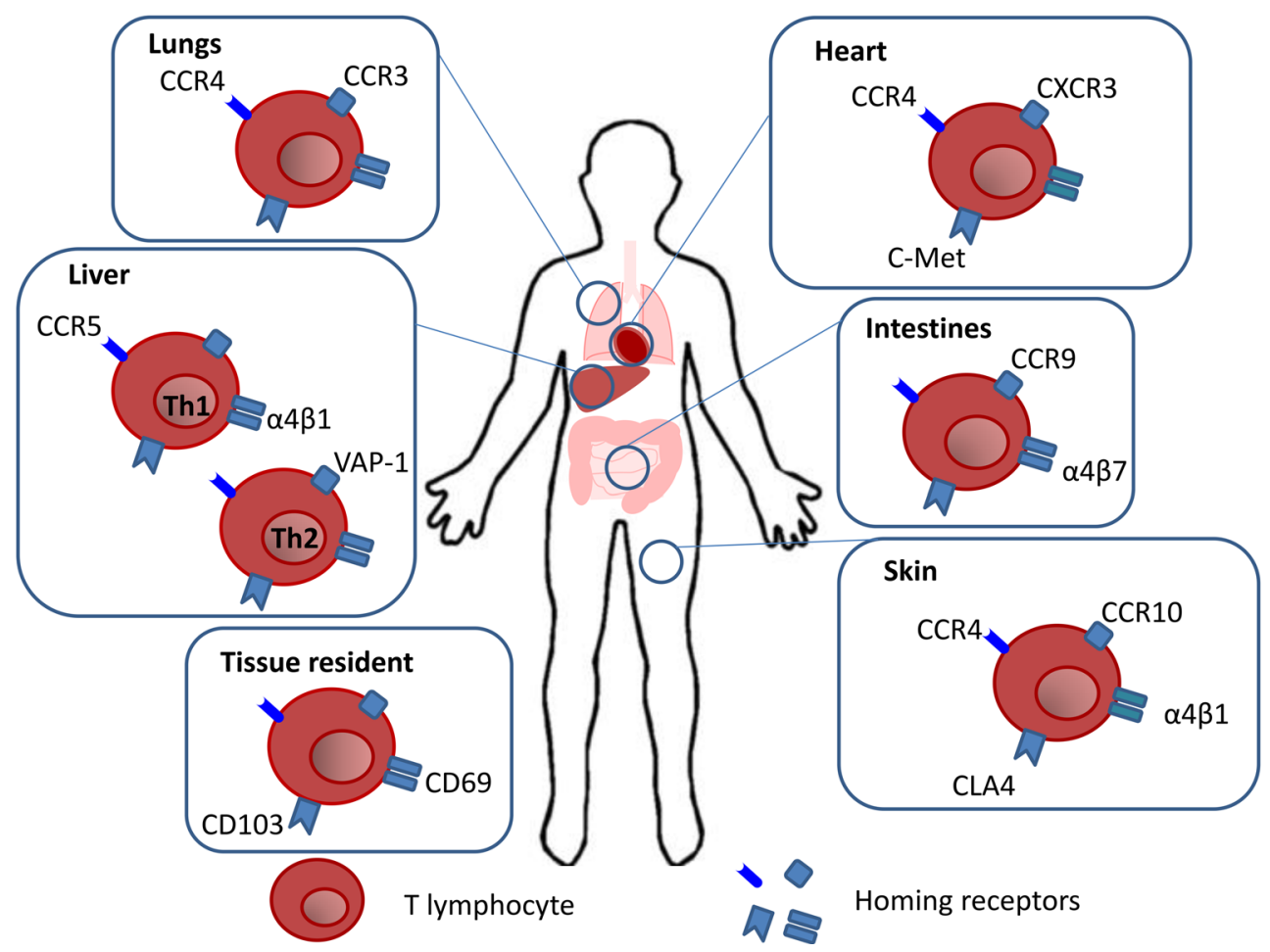

Fig. 1 Memory $\mathrm{T}$ cell tissue homing. Memory $\mathrm{T}$ lymphocytes acquire the expression of homing receptors, imprinted during priming in the draining LNs, which enable their migration to specific tissues. T cells trafficking to the heart occurs due to the expression of C-met which binds to its ligand HGF released by the heart. This binding induces the upregulation of CCR 4 and CXCR3. The interaction of $\alpha 4 \beta 7$ and CCR9 with their respective ligands MAdCAM-1 and CCL25 results in gut specific homing. Migration into the skin occurs due to the expression of CCR4, CCR10, $\alpha 4 \beta 1$ and CLA which

autoimmune diabetes in non-obese diabetic (NOD) mice in vivo was impaired in IFN- $\gamma$-deficient NOD mice [211]. In particular, $\mathrm{T}$ cell diapedesis was significantly diminished. This effect was reversible by treatment of the animals with recombinant IFN- $\gamma$. MHC class II molecule expression by microvascular endothelium in the CNS precedes and is required for the formation of $\mathrm{T}$ cell infiltrates in EAE in guinea pigs [212]. Presentation of cognate antigen by either ECs or bone marrow-derived APCs that extend into the capillary lumen was sufficient for $\mathrm{T}$ cell migration into graft tissues [213]. Intravital microscopy revealed that antigen presentation by the endothelium selectively enhances $\mathrm{T}$ cell diapedesis into the tissue without affecting rolling and adhesion.

TCR signals can also exert indirect effects on $T$ cell migration. The identification of a crosstalk between TCRand chemokine receptor-mediated signalling indicates that TCR-induced signals might also affect $\mathrm{T}$ cell responses to chemokines. Both TCR signalling and chemokine receptor signalling trigger downstream integrin activation, e.g, Lymphocyte function-associated antigen (LFA)-1 and interact with their respective ligands CCL17, CCL27, VCAM-1 and E-selectin on the endothelium. Th1 cell homing to the liver is been reported to use VLA-4 and CCR5 whereas Th2 cells use VAP-1 which is expressed on hepatic venules and liver sinusoids. CCL3 which binds to CCR3 and CCR4 have been shown to contribute to imprinting a lung homing signature. At the end of an immune reaction some $\mathrm{T}$ lymphocytes become tissue resident following upregulation of CD69 and CD103

VLA-4 [214, 215]. Moreover, signal transduction induced by CXCR4 in human $\mathrm{T}$ cells requires the zeta-associated protein 70 (ZAP-70), a key element in TCR signalling [216]. In addition, chemokine receptor expression is regulated by $\mathrm{T}$ cell activation [217]. Chemokines contribute to antigen-specific $\mathrm{T}$ cells homing following cognate recognition of the endothelium in vivo [209, 218].

The relative contribution of antigen-specific and nonantigen-specific signals to memory $\mathrm{T}$ cell recruitment is likely to be determined by the intensity of the inflammatory response. It is possible that TCR-mediated primed $\mathrm{T}$ cell localization to antigenic sites may be essential to ensure efficient, rapid memory responses in the event of limited inflammatory signals. For example, insulin-specific $\mathrm{T}$ cells are efficiently recruited to pancreatic islets of various mouse strains that are free of preexistent inflammation [209]. In contrast, severe inflammation or a pre-existing large antigen-specific $\mathrm{T}$ cell repertoire (for example during direct alloresponses) may override the requirement for selective antigen-dependent $\mathrm{T}$ cell recruitment [219]. 


\section{Co-stimulatory molecules regulate $\mathbf{T}$ cell migration}

Co-stimulatory signals such as those mediated by CD28 delivered to T cells in conjunction with TCR engagement are required to sustain $\mathrm{T}$ cell division, differentiation and survival [220]. Negative co-stimulators (such as CTLA-4) counteract these effects thus promoting homeostatic mechanisms and preventing autoimmunity. These costimulators have also been shown to regulate adhesion molecules activity and cytoskeletal rearrangement in vitro [221-223]. In vivo, CD28-mediated signals are required for primed $\mathrm{T}$ cells to leave lymphoid tissue following priming and promote the localization of $\mathrm{T}$ cells to target tissue. A prominent feature of $\mathrm{CD} 28$-deficient immune responses is the inefficient localization of primed $\mathrm{T}$ cells to non-lymphoid antigenic site [224-227]. TCR-transgenic T cells carrying a mutation in the cytoplasmic tail of CD28 $\left(\mathrm{CD} 28^{\mathrm{Y} 170 \mathrm{~F}}\right)$ that abrogates phosphatidylinositol-3'-kinase (PI3K) recruitment without leading to defects in clonal expansion failed to localize to target tissue following priming $[227,228]$.

The mechanism by which CD28 facilitates migration of primed $\mathrm{T}$ cells to non-lymphoid tissue is unclear. CD28 does not appear to directly mediate adhesion [229], but may favour primed $\mathrm{T}$ cell access to non-lymphoid tissue by inducing integrin mediated-adhesion. Additional mechanisms, such as transcriptional regulation of chemokine receptor expression by $\mathrm{CD} 28$, are likely to be involved [227, 230]. Despite sharing adhesion-inducing and promigratory properties in vitro [231], CTLA-4-mediated signals lead to effects antagonistic to those induced by CD28 on $\mathrm{T}$ cell migration in vivo. Tissue infiltration by murine $\mathrm{T}$ cells was abrogated by CTLA-4 ligation [227].

In addition to CD28 and CTLA-4, a number of other costimulatory molecules have been implicated in the regulation of $\mathrm{T}$ cell migration. For example, OX40/OX40 ligand interaction has been shown to be required for $\mathrm{T}$ cell migration to germinal centres [230], and the inducible costimulatory molecule (ICOS) regulates human memory $\mathrm{T}$ cell migration through tumour necrosis factor (TNF)- $\alpha$ treated ECs [232].

\section{Mechanisms of TCR- and costimulation-driven T cell trafficking: the central role of PI3K signals}

PI3K signaling mediates not only events downstream of TCR and CD28 [233, 234] leading to T cell division and differentiation, but also events leading to $\mathrm{T}$ cells migration. It has been shown that both TCR- and CD28-driven T cell migration rely upon PI3K p110 $\delta$ activity [227, 235-238]. Studies using $\mathrm{T}$ cells from mice expressing a catalytically inactive $\mathrm{p} 110 \delta$ isoform or treated with selective $\mathrm{p} 110 \delta$ inhibitor, revealed an essential role for this molecule in
TCR-dependent localization of both $\mathrm{CD}^{+}{ }^{+}$and $\mathrm{CD} 8^{+} \mathrm{T}$ cells in an antigen-specific transplantation model [235, 239]. Recent evidence also strongly correlates CD28-induced migration with PI3K (likely p1108) signalling. TCRtransgenic mice carrying an ovalbumin-specific $\mathrm{T}$ cell receptor (OT-II) and a mutation in the cytoplasmic tail of CD28 that abrogates class I PI3K recruitment without leading to defects in clonal expansion $\left(\mathrm{CD} 28^{\mathrm{Y} 170 \mathrm{~F}}\right)$ were generated to allow discrimination of conventional costimulation-driven clonal-expansion from their ability to infiltrate antigenic tissue (OT-II/CD28 $\left.28^{\mathrm{Y} 170 \mathrm{~F}}\right)$. OT-II and $\mathrm{OT}-\mathrm{II} / \mathrm{CD} 28^{\mathrm{Y} 170 \mathrm{~F}}$ naïve $\mathrm{T}$ cells proliferated equivalently following immunization with antigenic peptide. Unlike OT-II cells, However, OT-II/CD28 ${ }^{\mathrm{Y} 170 \mathrm{~F}} \mathrm{CD} 8^{+}$memory T cells failed to localize to target tissue upon antigen challenge [228].

A few mechanisms have been suggested to account for the role of TCR- and CD28-induced PI3K signaling in memory $\mathrm{T}$ cell migration into target tissue. Naïve $\mathrm{T}$ cells express CD62L, CCR7 and S1PR1, which facilitate their trafficking to SLOs. Following TCR and CD28 engagement, the PI3K-Akt-mTOR axis promotes the transcriptional downregulation of CD62L, CCR7 and S1PR1 via the inhibition of the transcription factor KLF2, leading to $T$ cells egress from draining LNs and traffic into nonlymphoid tissues [93, 94, 240, 241]. PI3K-Akt signaling has also been implicated in F-actin polymerization and myosin assembly [242-245]. Accordingly, PI3K(s) contribute to several aspects of the migratory machinery, including gradient sensing, signal amplification, actin reorganization and hence cell motility [246-248].

Activation of PI3K is also a robust signaling event shared by most homoeostatic and inflammatory chemokine receptors expressed on $\mathrm{T}$ cells [249]. There has been interest in exploring the role of PI3K-dependent signaling in the $\mathrm{T}$ cell migratory responses after chemokine stimulation. Pharmacological and genetic approaches have been employed to assess the contribution of individual class I PI3K isoforms to the T-lymphocyte's migratory response to several chemokines. In contrast to TCR or CD28-induced migration, PI3K inhibitors were found to have little effect on chemokine induced $\mathrm{T}$ cell migration both in vitro and in vivo. T-lymphocyte arrest and adhesion to HEVs in exteriorized PP [250] or transendothelial migration in laminar-flow chambers [251] in response to either CXCR4 and/or CCR7 ligation is unaffected by PI3K inhibitors. There was no defect in the $110 \delta$ mutant mice of either normal constitutive trafficking or migratory response to chemokines. Further studies revealed that responses to chemokines in $\mathrm{T}$ cells require a largely PI3K-independent activation of the small GTPase DOCK2, a mammalian homolog of Caenorhabditis elegans CED-5 and Drosophila melanogaster Myoblast City [252]. 


\section{Regulatory $\mathbf{T}$ cell (Treg) trafficking}

Tregs were first identified in mice by Sakaguchi and coworkers in 1995 as a subset of $\mathrm{CD} 4^{+} \mathrm{T}$ cells with a constitutive expression of IL-2 receptor alpha-chain CD25 [253]. Tregs are characterized by constitutive expression of the transcription factor FoxP3, which confers on them potent suppressive activity [254, 255]. Tregs suppression requires activation signals via the TCR; however, once activated their suppressor function is antigen non-specific [256]. Tregs exert their function by suppressing effector $\mathrm{T}$ cell responses, thus preventing the development of autoimmunity [257, 258]. Mice with a spontaneous mutation in the FoxP3 gene-known as 'scurfy' mice—develop fatal autoimmune diseases affecting multiple organs [254]. Similarly, humans with mutations affecting the FoxP3 gene suffer from severe autoimmunity (IPEX: immune polyendocrine enteropathy X-linked syndrome) [255]. In scurfy mice and IPEX patients, chronically activated self-reactive $\mathrm{CD}^{+} \mathrm{T}$ cells are found to be responsible for the development of pathology [259].

Naturally occurring Tregs (nTregs) develop in the thymus and constitute approximately $5-10 \%$ of all peripheral $\mathrm{CD}^{+}{ }^{+} \mathrm{T}$ cells in mice [260]. In mice, both $\mathrm{CD} 25^{\text {high }}$ and $\mathrm{CD} 25^{\text {low }}$ of the $\mathrm{CD} 4^{+} \mathrm{CD} 25^{+}$population exhibit suppressor functions. However, in humans only $\mathrm{CD} 4{ }^{+} \mathrm{CD} 25^{\text {high }} \mathrm{T}$ cells are suppressive [261]. Human $\mathrm{CD} 4^{+} \mathrm{CD} 25^{\text {high }}$ Tregs account for $1-2 \%$ of the total peripheral $\mathrm{CD}^{+}{ }^{+} \mathrm{T}$ cell population [261]. It must also be considered that high levels of CD25 and FoxP3 are transiently expressed by recently activated human $\mathrm{T}$ cells, which do not display suppressor functions [262, 263]. Thus, a human Tregsspecific marker has yet to be identified. Despite this, markers important for the survival and the suppressive functions of Tregs have been identified such as CTLA-4 and glucocorticoid-induced TNF-receptor-related protein (GITR) [264, 265].

\section{Induced Tregs (iTregs)}

Aside from nTregs, Tregs can also be induced from naïve $\mathrm{CD} 4{ }^{+} \mathrm{CD} 25^{-} \mathrm{T}$ cells both in vitro and in vivo [266-268]. Both nTregs and iTregs do not proliferate in vitro and are able to suppress effector $\mathrm{T}$ cell responses both in vitro and in vivo [269]. Thus far, the differentiation of naïve T cells into iTregs in vivo has been documented in the murine intestine [177], inflamed lung [270], tumours [271] and transplanted tissues [272].

The possible underlying mechanisms of iTregs generation have also been explored in both humans and mice. In vitro generation of iTregs has been shown to be dependent on TGF- $\beta$ and IL-2 [266, 273]. The VA metabolite RA also facilitates the generation of Tregs mediated by TGF- $\beta$ following priming by DCs in the secondary lymphoid tissue $[177,180]$. In addition, studies have shown that $\mathrm{CD}_{103^{+}}$DCs in the small intestinal LPs and the MLNs are capable of generating FoxP3 ${ }^{+}$Tregs in the presence of TGF- $\beta$ and RA [177, 180]. ITregs can also be generated from $\mathrm{CD} 4^{+} \mathrm{CD} 25^{-} \mathrm{T}$ cells cultured with rapamycin [274].

ITregs generated under different conditions may display different migratory patterns. iTregs generated in the presence of RA also express fully functional gut-homing receptors $\alpha_{4} \beta_{7}$ and CCR9, therefore they migrate primarily to the gut [200]. ITregs generated in the presence of rapamycin express relatively high levels of CCR7 and possess a relatively greater lymphoid tissue-homing capacity [275]. Different characteristics of iTreg generated with different methods need to be taken into consideration when designing therapies for immune-mediated disorders.

\section{Treg homing to SLOs}

Treg-mediated immune suppression operates in both SLOs [276] and non-lymphoid tissue [277, 278]. Appropriate trafficking and retention mediated by distinct chemokine and adhesion receptors are indispensable for Tregs to efficiently modulate immune response at sites where regulation is required [279-281]. nTregs express CD62L and CCR7, which facilitate their homing to the $\mathrm{T}$ cell area of LNs [276, 282, 283]. At the T cell zone, naïve Tregs may recognize antigens and become activated [284]. Upon activation, Tregs lose CCR7 expression and reduce CD62L expression $[285,286]$ and gain the expression of CXCR5, a chemokine receptor that promotes Treg migration into germinal centres in response to CXCL13, where they regulate the magnitude and characteristics of antibody responses [287, 288].

Migration to SLOs is required for Tregs to control the induction phase of an immune response [276, 289]. It was uncovered that $\mathrm{CD}_{2} \mathrm{~L}^{+}$Treg homing to LNs is necessary for the induction of transplantation tolerance [290]. $\mathrm{CD} 2 \mathrm{~L}^{+}$Tregs, rather than $\mathrm{CD} 62 \mathrm{~L}^{-}$Tregs, protect from acute graft-versus-host disease (GVHD) [291, 292] and efficiently delay diabetes in pre-diabetic NOD mice [293]. In contrast, Tregs from CCR7 knockout mice were inefficient in homing to LNs and did not suppress antigeninduced activation of T cell [294].

Within SLOs, Tregs need close physical contact with effector cells to exert their regulatory function [295]. Thus, effective suppression can only occur when homing of Tregs runs in parallel with that of effector $\mathrm{T}$ cells. Evidence suggests that Tregs and effector $\mathrm{T}$ cells home to similar areas of the LNs [289]. In a model of diabetes, in vivo two- 
photon microscopy revealed that Tregs co-localised with diabetogenic $\mathrm{T}$ cells in pancreatic LNs, and inhibited their antigen-dependent swarming and arrest [289]. Furthermore, using a recently described multiplex, quantitative imaging termed histocytometry, Liu et al. observed that within secondary lymphoid tissues in mice, Tregs exist in discrete clusters with IL-2-producing $\mathrm{CD}^{+}{ }^{+} \mathrm{T}$ cells. Disruption of their physical co-clustering with effector $\mathrm{T}$ cells by inducible ablation of TCR expression by Tregs resulted in uncontrolled effector T cell responses [296].

\section{Treg cell homing to non-lymphoid tissue}

Tregs need to migrate from circulation to non-lymphoid sites of inflammation to control effector immune responses [285, 297, 298]. Similarly to conventional T cells, Tregs in the microvasculature must undergo rolling, adhesion and transmigration mediated by distinct chemokine and adhesion receptors to arrive at the site of inflammation. Selectin ligands play a vital role for appropriate Tregs localisation in the periphery, particularly in the skin. In steady-state conditions, low-frequency rolling in dermal microvessels were P-selectin-dependent, whereas during most phases of inflammation, P-selectin and E-selectin both contributed to rolling [299]. Mice lacking PSGL-1, the main ligand required for P-selectin-dependent rolling, develop a more severe form of the EAE model of multiple sclerosis [300]. FucTVII, the enzyme responsible for generation of functional selectin ligands, is required for selectin-mediated leukocyte rolling in the microvasculature and leukocyte entry into the skin [301, 302]. Despite having normal in vitro regulatory capacity and populating lymphoid organs and peripheral sites such as the lung and intestine as efficiently as FucTVII sufficient Tregs, FucTVII deficient Tregs were severely restricted in their homing capacity to the skin, and unable to regulate contact hypersensitivityassociated skin inflammation [297].

Like conventional $\mathrm{T}$ cells, Treg trafficking to different tissues is determined by the combined expression of chemokine receptors and adhesion molecules [303]. Activated Tregs express $\alpha_{\mathrm{E}} \beta_{7}$, which binds its ligand E-cadherin and might predispose their retention to epithelial sites of inflammation in the periphery [285, 304]. Conversely, the $\alpha_{\mathrm{E}}^{-}$Treg population was shown to be more efficient than $\alpha_{\mathrm{E}}^{+}$ Tregs at homing to LNs [297]. It has been shown that increased CLA or $\alpha_{4} \beta_{7}$ expression by circulating human Tregs is associated with reduced risk of skin or gut acute GVHD, respectively [305]. Also like conventional T cells, the migratory properties of Tregs are shaped by the tissue microenvironment and organ-resident DCs during priming [198]. Tregs activated in the LNs draining a tissue acquire homing receptors that allow them to migrate back to the inflamed tissue. For example, Tregs activated in MLNs and
PPs acquire $\alpha_{4} \beta_{7}$ and CCR9, which direct their trafficking to the gut. By contrast, Tregs activated in PLNs express CCR8, which promote their migration to the skin [306].

Recent studies have shown that a large proportion of circulating human Tregs express the skin-homing receptors CLA and CCR4. In contrast, only a small number of circulating Tregs express gut-homing receptors $\alpha_{4} \beta_{7}$ and CCR9 and $\alpha_{E} \beta_{7}[307,308]$. This observation raises the question of how Tregs execute their suppressor functions in the gut [264]. A possible explanation is that MAdCAM-1, expressed constitutively on the postcapillary venules of intestine, is also capable of binding to CD62L found on Tregs in humans and mice $[15,297,309]$. CD62L therefore may target Tregs to the MLNs and the PPs where they carry out suppressor functions [307].

There is also evidence to suggest that Tregs can recirculate between SLOs and non-lymphoid tissues. A study by Tomura et al. showed that in steady-state Tregs constitutively migrated from the skin to draining LNs in mice. During skin inflammation, Tregs in circulation infiltrate the periphery, traffic to dLNs, and then recirculate back to the skin [310]. By doing so, Tregs can efficiently regulate both the induction phase and effector phase of immune response.

Treg migration to the inflamed liver has been shown to be supported by the common lymphatic endothelial and vascular endothelial receptor (CLEVER-1; also known as FEEL-1 and stabilin-1). Shetty and colleagues demonstrated increased endothelial expression of CLEVER-1 at sites of leukocyte recruitment to the inflamed human liver including sinusoids, septal vessels, and lymphoid follicles in inflammatory liver disease and tumor-associated vessels in hepatocellular carcinoma. Together with ICAM-1 and vascular adhesion protein-1 (VAP-1), CLEVER-1 can support transcellular migration of Tregs. CLEVER-1 inhibition reduced Treg transendothelial migration by $40 \%$ and when combined with blockade of ICAM- 1 and VAP-1 reduced it by $>80 \%$ [311].

The bone marrow is a critical site of immunity as studies have shown that long-lived, antibody-secreting plasma cells [312] and functional memory $\mathrm{T}$ cells $[52,53]$ reside in this organ. A subset of activated Tregs up-regulates CXCR4 expression and become responsive to SDF-1, enabling them to migrate to the bone marrow [313], where Tregs can suppress immune responses [53, 312, 314]. It has been described that in bone marrow of human and mice more than $25 \%$ of $\mathrm{CD}^{+}{ }^{+} \mathrm{T}$ cells are Tregs-as compared to $5-10 \%$ of $\mathrm{CD}^{+} \mathrm{T}$ cells which are Tregs in the peripheral blood. Tregs exit from the bone marrow is achieved through granulocyte colony-stimulating factor (G-CSF) and reduced expression of SDF-1 [313]. Thus, it appears that Tregs are actively, rather than passively, recruited and retained in the bone marrow to regulate immune responses during homeostasis. 
Long-term resident Tregs have been found in a wide range of tissues under homeostatic conditions, such as skin, gastrointestinal tract, lung, liver and adipose tissue [315-318]. Expression of particular sets of chemokine receptors not only is involved with Tregs recruitment to specific tissue sites, but also may facilitate retention of Tregs. Antigen recognition is also important in Treg survival and development of tissue tropic activity [319]. We and others have demonstrated that expression of TCR specific for an antigen expressed in a given tissue by Tregs promotes its recruitment, retention and clonal expansion in that location $[320,321]$. nTregs predominantly recognise self-antigens [319]. We have reported that nTreg recognition of self-antigens expressed by endothelial cells in target tissue is instrumental for efficient Treg recruitment in vivo [320]. This may explain why recipient-derived Tregs are less efficient at modulating rejection of vascularized tissue graft [322]. A recent human study showed that Tregs comprise a high proportion $(30-40 \%)$ of $\mathrm{CD}^{+} \mathrm{T}$ cells in paediatric tissues but are present at much lower frequencies (1-10\%) in adult tissues. Paediatric tissue Treg cells suppress endogenous $\mathrm{T}$ cell proliferation and function, avoiding excessive activation as a result of diverse new antigens in early life [323]. Similarly, murine study by Scharschmidt et al. observed the accumulation of antigen-specific Tregs in neonatal skin is required to establish tolerance to skin commensals. Transiently blocking the migration of Tregs into the skin with S1PR1 antagonist FTY720 between postnatal days 5 and 11 to block the egress of lymphocytes from the thymus and skin dLNs [42] led to increased skin inflammation after challenge with same skin commensal bacteria in adult mice. This inflammation was associated with a reduction of antigen-specific Tregs and increased numbers of antigen-specific effector $\mathrm{CD} 4^{+}$ $\mathrm{T}$ cells in the skin and skin dLNs [324]. The roles of tissue homing and antigen recognition are intertwined. Tregs utilize tissue homing molecules to migrate to the site of cognate antigen expression and lymphoid organs draining that site, and then receive TCR-derived signals that are critical to its survival and proliferation [325].

The number of Tregs in tissue has been observed to increase during inflammation. Regarding the relative contributions of tissue-resident versus recently recruited Tregs in the regulation of inflammation, it has been suggested that tissue-resident Tregs are sufficient to restrict mild inflammation stemming from recognition of commensal microbes or self-antigen in the periphery, but upon recognition of foreign microbial antigen, recruitment of additional Tregs is necessary to keep inflammation under control [315].

Tregs have been used to suppress allograft rejection in transplantation settings. $\mathrm{T}$ effector cells with high avidity for donor antigens migrate to an allograft to mediate transplant rejection [326]. Tregs must be able to migrate to transplanted organs to effectively suppress intra-graft antidonor immune response. Intra-graft Tregs have been associated with tolerance induction. Tregs with unique chemokine profile have been shown to migrate to different graft tissues. CCR4 expression is associated with the recruitment of Tregs in heart allograft of tolerant mice [278]. Chemokine receptors CCR2, CCR4, CCR5 and Pand E-selectin ligands expression determines Tregs migration into islet allografts. CCR5 has been shown to play an important role in Tregs recruitment to both lymphoid tissues and GVHD target organs [327].

A summary of the different homing pathways used by Treg cells is summarized in Fig. 2.

Emerging evidence suggests that Treg trafficking and compartmentalization can be modulated allowing efficient tissue targeting following ex vivo expansion. Siewert and colleagues have shown that Tregs can be configured both in vitro and in vivo with organ-selective homing properties allowing efficient migration into target tissue. For example, $\alpha_{4} \beta_{7}^{+}$Tregs generated in vitro are able to effectively clear acute inflammation in the small intestine when transferred into the diseased animals [328]. This suggests that modulation of Tregs designed to serve for therapeutic purposes with specific homing properties is feasible for adoptive $\mathrm{T}$ cell therapy.

\section{Concluding remarks}

While the majority of existing vaccines rely on circulating antibody for long-lasting protection, unique challenges posed by HIV or other sexually transmitted infections such as HSV require $\mathrm{T}$ cell-based vaccines or a combination of both $\mathrm{T}$ and $\mathrm{B}$ cell based vaccines. Successful T cell-based vaccination strategies depend not only on the generation of immunological memory against pathogen, but also on topographic memory of sites of infection as well as the establishment of $\mathrm{T}_{\mathrm{RM}}$. Further understanding of how $\mathrm{T}$ cell tissue tropism is generated and maintained will aid in the design of efficacious vaccines. Due to the effect of local microenvironment on tissue homing acquisition, efforts should be made to design a vaccine that uses local immunization. Studies have shown that mucosal vaccination induces more recruitment of antigen-specific $\mathrm{T}$ cells to mucosal sites compared to distal immunization [329]. However, the recent finding that soluble factors can induce the acquisition of $\mathrm{T}$ cell homing receptors to selected tissue paves the way to the generation of combinatorial vaccines including 'cues' for the design of the desired tissue tropism.

A relatively unexplored issue is the plasticity of topographic memory. Understanding the genetic and epigenetic regulation of homing receptor expression will be crucial to the design of vaccination schedules involving 


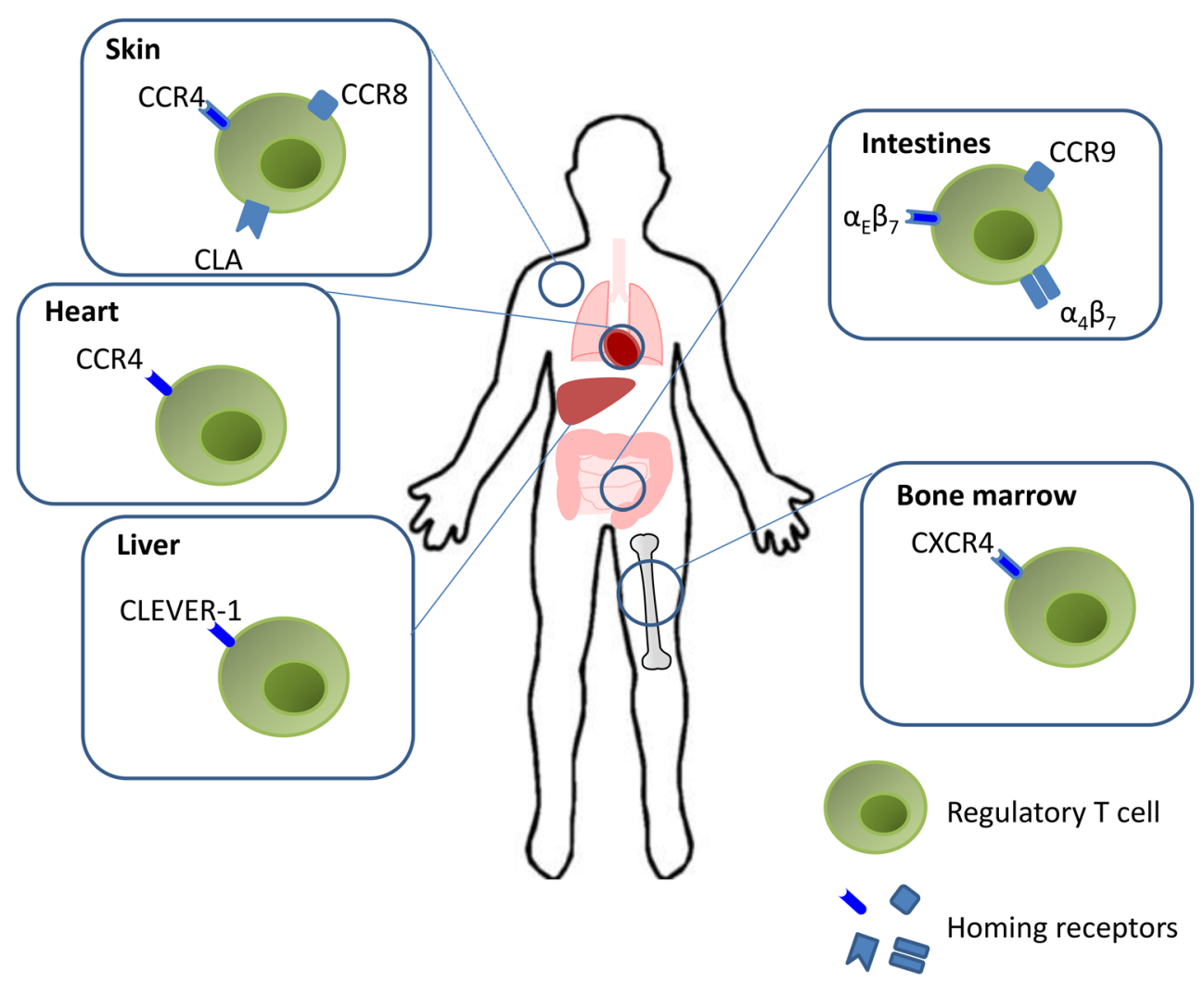

Fig. 2 Regulatory $\mathrm{T}$ cell tissue homing. Modulation of immune responses by Tregs requires appropriate trafficking and retention. Homing signatures are mediated by distinct chemokine and adhesion molecules. Activated Tregs are predisposed to retention in the periphery due to the interaction of $\alpha_{\mathrm{E}} \beta_{7}$ with E-cadherin. Tregs expressing $\alpha_{4} \beta_{7}$ and CCR9 migrate to the intestines. A subset of activated Tregs up-regulate CXCR4 expression and become

combinatorial formulations. If, as it has been suggested, $\mathrm{T}$ cell trafficking programming is plastic, the possibility of reprogramming $\mathrm{T}$ cell tissue tropism upon a second antigen encounter provides great potential for a variety of therapeutic manipulations of immune responses.

Acknowledgments F.M.M.-B. is supported by the British Heart Foundation, the Medical Research Council of the UK and the Gates Foundation.

Open Access This article is distributed under the terms of the Creative Commons Attribution 4.0 International License (http:// creativecommons.org/licenses/by/4.0/), which permits unrestricted use, distribution, and reproduction in any medium, provided you give appropriate credit to the original author(s) and the source, provide a link to the Creative Commons license, and indicate if changes were made.

\section{References}

1. Wiedle G, Dunon D, Imhof BA (2001) Current concepts in lymphocyte homing and recirculation. Crit Rev Clin Lab Sci 38:1-31. doi:10.1080/20014091084164 responsive to SDF-1, enabling them to migrate to the bone marrow. Treg homing to the inflamed liver is mediated by interactions of the Tregs with hepatic sinusoidal endothelial cell expression of CLEVER-1. CCR4 expression is associated with the recruitment of Tregs in heart allograft of tolerant mice. Similar to effector T cells, Tregs express the skin-homing receptors CLA and CCR4 that bind to E-selectin and CCL17 respectively

2. Janeway CA (2005) Immunobiology: the immune system in health and disease, 6th edn. Garland Science, New York

3. Yonekawa K, Harlan JM (2005) Targeting leukocyte integrins in human diseases. J Leukoc Biol 77:129-140

4. Grossman WJ, Verbsky JW, Barchet W, Colonna M, Atkinson JP, Ley TJ (2004) Human T regulatory cells can use the perforin pathway to cause autologous target cell death. Immunity 21:589-601. doi:10.1016/j.immuni.2004.09.002

5. Diamond MS, Springer TA (1994) The dynamic regulation of integrin adhesiveness. Curr Biol 4:506-517. pii: S09609822(00)00111-1

6. Johnston B, Butcher EC (2002) Chemokines in rapid leukocyte adhesion triggering and migration. Semin Immunol 14:83-92

7. Fabbri M, Bianchi E, Fumagalli L, Pardi R (1999) Regulation of lymphocyte traffic by adhesion molecules. Inflamm Res 48:239-246

8. Nourshargh S, Marelli-Berg FM (2005) Transmigration through venular walls: a key regulator of leukocyte phenotype and function. Trends Immunol 26:157-165

9. Engelhardt B, Wolburg H (2004) Mini-review: transendothelial migration of leukocytes: through the front door or around the side of the house? Eur J Immunol 34:2955-2963. doi:10.1002/ eji.200425327

10. Nourshargh S, Alon R (2014) Leukocyte migration into inflamed tissues. Immunity 41:694-707

11. Ley K, Kansas GS (2004) Selectins in T-cell recruitment to nonlymphoid tissues and sites of inflammation. Nat Rev Immunol 4:325-335. doi:10.1038/nri1351 
12. Butcher EC, Williams M, Youngman K, Rott L, Briskin M (1999) Lymphocyte trafficking and regional immunity. Adv Immunol 72:209-253

13. Lewis M, Tarlton JF, Cose S (2008) Memory versus naive T-cell migration. Immunol Cell Biol 86:226-231. doi:10.1038/sj.icb. 7100132

14. Butcher EC, Picker LJ (1996) Lymphocyte homing and homeostasis. Science 272:60-66

15. Picker LJ, Butcher EC (1992) Physiological and molecular mechanisms of lymphocyte homing. Annu Rev Immunol 10:561-591. doi:10.1146/annurev.iy.10.040192.003021

16. Shimizu Y, van Seventer GA, Horgan KJ, Shaw S (1990) Roles of adhesion molecules in T-cell recognition: fundamental similarities between four integrins on resting human T cells (LFA-1, VLA-4, VLA-5, VLA-6) in expression, binding, and costimulation. Immunol Rev 114:109-143

17. Mackay CR (1993) Immunological memory. Adv Immunol 53:217-265

18. Vitetta ES, Berton MT, Burger C, Kepron M, Lee WT, Yin XM (1991) Memory B and T cells. Annu Rev Immunol 9:193-217. doi:10.1146/annurev.iy.09.040191.001205

19. Sprent J (1994) T and B memory cells. Cell 76:315-322. pii: 0092-8674(94)90338-7

20. Garcia de Tena J, Manzano L, Leal JC, San Antonio E, Sualdea V, Alvarez-Mon M (2006) Distinctive pattern of cytokine production and adhesion molecule expression in peripheral blood memory $\mathrm{CD}^{+}{ }^{+} \mathrm{T}$ cells from patients with active Crohn's disease. J Clin Immunol 26:233-242

21. von Andrian UH, Mempel TR (2003) Homing and cellular traffic in lymph nodes. Nat Rev Immunol 3:867-878

22. Mackay CR, Marston WL, Dudler L (1990) Naive and memory $\mathrm{T}$ cells show distinct pathways of lymphocyte recirculation. J Exp Med 171:801-817

23. Streeter PR, Rouse BT, Butcher EC (1988) Immunohistologic and functional characterization of a vascular addressin involved in lymphocyte homing into peripheral lymph nodes. J Cell Biol 107:1853-1862

24. Williams O, Tarazona R, Wack A, Harker N, Roderick K, Kioussis D (1998) Interactions with multiple peptide ligands determine the fate of developing thymocytes. Proc Natl Acad Sci USA 95:5706-5711

25. Baekkevold ES, Yamanaka T, Palframan RT, Carlsen HS, Reinholt FP, von Andrian UH, Brandtzaeg P, Haraldsen G (2001) The CCR7 ligand elc (CCL19) is transcytosed in high endothelial venules and mediates T cell recruitment. J Exp Med 193:1105-1112

26. Bargatze RF, Jutila MA, Butcher EC (1995) Distinct roles of L-selectin and integrins alpha 4 beta 7 and LFA-1 in lymphocyte homing to Peyer's patch-HEV in situ: the multistep model confirmed and refined. Immunity 3:99-108

27. Campbell DJ, Kim CH, Butcher EC (2003) Chemokines in the systemic organization of immunity. Immunol Rev 195:58-71

28. Besedovsky L, Linz B, Born J, Lange T (2014) Mineralocorticoid receptor signaling reduces numbers of circulating human naive $\mathrm{T}$ cells and increases their CD62L, CCR7, and CXCR4 expression. Eur J Immunol 44:1759-1769

29. Vestweber D (2003) Lymphocyte trafficking through blood and lymphatic vessels: more than just selectins, chemokines and integrins. Eur J Immunol 33:1361-1364

30. Weninger W, Carlsen HS, Goodarzi M, Moazed F, Crowley MA, Baekkevold ES, Cavanagh LL, von Andrian UH (2003) Naive $\mathrm{T}$ cell recruitment to nonlymphoid tissues: a role for endothelium-expressed CC chemokine ligand 21 in autoimmune disease and lymphoid neogenesis. J Immunol 170:4638-4648
31. Moussion C, Girard JP (2011) Dendritic cells control lymphocyte entry to lymph nodes through high endothelial venules. Nature 479:542-546

32. Kiermaier E, Moussion C, Veldkamp CT, Gerardy-Schahn R, de Vries I, Williams LG, Chaffee GR, Phillips AJ, Freiberger F, Imre R et al (2016) Polysialylation controls dendritic cell trafficking by regulating chemokine recognition. Science 351:186-190

33. Silva-Filho JL, Souza MC, Henriques MG, Morrot A, Savino W, Caruso-Neves C, Pinheiro AA (2015) Renin-angiotensin system contributes to naive T-cell migration in vivo. Arch Biochem Biophys 573:1-13

34. Berlin C, Berg EL, Briskin MJ, Andrew DP, Kilshaw PJ, Holzmann B, Weissman IL, Hamann A, Butcher EC (1993) Alpha 4 beta 7 integrin mediates lymphocyte binding to the mucosal vascular addressin MAdCAM-1. Cell 74:185-195

35. Erle DJ, Briskin MJ, Butcher EC, Garcia-Pardo A, Lazarovits AI, Tidswell M (1994) Expression and function of the MAdCAM-1 receptor, integrin alpha 4 beta 7, on human leukocytes. J Immunol 153:517-528

36. Rott LS, Briskin MJ, Andrew DP, Berg EL, Butcher EC (1996) A fundamental subdivision of circulating lymphocytes defined by adhesion to mucosal addressin cell adhesion molecule- 1 . Comparison with vascular cell adhesion molecule-1 and correlation with beta 7 integrins and memory differentiation. J Immunol 156:3727-3736

37. Wagner N, Lohler J, Tedder TF, Rajewsky K, Muller W, Steeber DA (1998) L-selectin and beta7 integrin synergistically mediate lymphocyte migration to mesenteric lymph nodes. Eur J Immunol 28:3832-3839. doi:10.1002/(SICI)15214141(199811)28:11<3832:AID-IMMU3832>3.0.CO;2-J

38. Mandl JN, Liou R, Klauschen F, Vrisekoop N, Monteiro JP, Yates AJ, Huang AY, Germain RN (2012) Quantification of lymph node transit times reveals differences in antigen surveillance strategies of naive $\mathrm{CD}^{+}$and $\mathrm{CD}^{+} \mathrm{T}$ cells. Proc Natl Acad Sci USA 109:18036-18041

39. Pham TH, Okada T, Matloubian M, Lo CG, Cyster JG (2008) S1P1 receptor signaling overrides retention mediated by $\mathrm{G}$ alpha $\mathrm{i}$-coupled receptors to promote $\mathrm{T}$ cell egress. Immunity $28: 122-133$

40. Shiow LR, Rosen DB, Brdickova N, Xu Y, An J, Lanier LL, Cyster JG, Matloubian M (2006) CD69 acts downstream of interferon-alpha/beta to inhibit S1P1 and lymphocyte egress from lymphoid organs. Nature 440:540-544

41. Grigorova IL, Schwab SR, Phan TG, Pham TH, Okada T, Cyster JG (2009) Cortical sinus probing, S1P1-dependent entry and flow-based capture of egressing T cells. Nat Immunol 10:58-65

42. Matloubian M, Lo CG, Cinamon G, Lesneski MJ, Xu Y, Brinkmann V, Allende ML, Proia RL, Cyster JG (2004) Lymphocyte egress from thymus and peripheral lymphoid organs is dependent on S1P receptor 1. Nature 427:355-360

43. Sprent J (1980) Antigen-induced selective sequestration of $T$ lymphocytes: role of the major histocompatibility complex. Monogr Allergy 16:233-244

44. Pappu R, Schwab SR, Cornelissen I, Pereira JP, Regard JB, Xu Y, Camerer E, Zheng YW, Huang Y, Cyster JG et al (2007) Promotion of lymphocyte egress into blood and lymph by distinct sources of sphingosine-1-phosphate. Science 316:295-298

45. Davidson TS, Shevach EM (2011) Polyclonal Treg cells modulate T effector cell trafficking. Eur J Immunol 41:2862-2870

46. Liu G, Yang K, Burns S, Shrestha S, Chi H (2010) The S1P(1)mTOR axis directs the reciprocal differentiation of $\mathrm{T}(\mathrm{H}) 1$ and T(reg) cells. Nat Immunol 11:1047-1056

47. Sallusto F, Geginat J, Lanzavecchia A (2004) Central memory and effector memory $\mathrm{T}$ cell subsets: function, generation, and maintenance. Annu Rev Immunol 22:745-763 
48. Sallusto F, Lenig D, Forster R, Lipp M, Lanzavecchia A (1999) Two subsets of memory $\mathrm{T}$ lymphocytes with distinct homing potentials and effector functions. Nature 401:708-712

49. Sprent J, Webb SR (1995) Intrathymic and extrathymic clonal deletion of $\mathrm{T}$ cells. Curr Opin Immunol 7:196-205. pii: 0952-7915(95)80004-2

50. Kaech SM, Wherry EJ (2007) Heterogeneity and cell-fate decisions in effector and memory $\mathrm{CD} 8^{+} \mathrm{T}$ cell differentiation during viral infection. Immunity 27:393-405

51. Manjunath N, Shankar P, Wan J, Weninger W, Crowley MA, Hieshima K, Springer TA, Fan X, Shen H, Lieberman J et al (2001) Effector differentiation is not prerequisite for generation of memory cytotoxic T lymphocytes. J Clin Invest 108:871-878. doi:10.1172/JCI13296

52. Becker TC, Coley SM, Wherry EJ, Ahmed R (2005) Bone marrow is a preferred site for homeostatic proliferation of memory CD8 T cells. J Immunol 174:1269-1273

53. Mazo IB, Honczarenko M, Leung H, Cavanagh LL, Bonasio R, Weninger W, Engelke K, Xia L, McEver RP, Koni PA et al (2005) Bone marrow is a major reservoir and site of recruitment for central memory $\mathrm{CD}^{+} \mathrm{T}$ cells. Immunity 22:259-270

54. Zou YR, Kottmann AH, Kuroda M, Taniuchi I, Littman DR (1998) Function of the chemokine receptor CXCR4 in haematopoiesis and in cerebellar development. Nature 393:595-599

55. Chaix J, Nish SA, Lin WH, Rothman NJ, Ding L, Wherry EJ, Reiner SL (2014) Cutting edge: CXCR4 is critical for $\mathrm{CD}^{+}$. memory $\mathrm{T}$ cell homeostatic self-renewal but not rechallenge self-renewal. J Immunol 193:1013-1016

56. von Andrian UH, Mackay CR (2000) T-cell function and migration. Two sides of the same coin. $\mathrm{N}$ Engl $\mathrm{J}$ Med 343:1020-1034

57. Klonowski KD, Williams KJ, Marzo AL, Blair DA, Lingenheld EG, Lefrancois L (2004) Dynamics of blood-borne CD8 memory $\mathrm{T}$ cell migration in vivo. Immunity $20: 551-562$

58. Masopust D, Vezys V, Usherwood EJ, Cauley LS, Olson S, Marzo AL, Ward RL, Woodland DL, Lefrancois L (2004) Activated primary and memory CD8 T cells migrate to nonlymphoid tissues regardless of site of activation or tissue of origin. J Immunol 172:4875-4882

59. Gebhardt T, Wakim LM, Eidsmo L, Reading PC, Heath WR, Carbone FR (2009) Memory T cells in nonlymphoid tissue that provide enhanced local immunity during infection with herpes simplex virus. Nat Immunol 10:524-530

60. Zammit DJ, Turner DL, Klonowski KD, Lefrancois L, Cauley LS (2006) Residual antigen presentation after influenza virus infection affects CD8 $\mathrm{T}$ cell activation and migration. Immunity 24:439-449

61. Hofmann M, Pircher H (2011) E-cadherin promotes accumulation of a unique memory CD8 T-cell population in murine salivary glands. Proc Natl Acad Sci USA 108:16741-16746

62. Masopust D, Choo D, Vezys V, Wherry EJ, Duraiswamy J, Akondy R, Wang J, Casey KA, Barber DL, Kawamura KS et al (2010) Dynamic $T$ cell migration program provides resident memory within intestinal epithelium. J Exp Med 207:553-564

63. Wakim LM, Woodward-Davis A, Bevan MJ (2010) Memory T cells persisting within the brain after local infection show functional adaptations to their tissue of residence. Proc Natl Acad Sci USA 107:17872-17879

64. O'Shea JJ, Paul WE (2010) Mechanisms underlying lineage commitment and plasticity of helper $\mathrm{CD}^{+} \mathrm{T}$ cells. Science 327:1098-1102

65. Cosmi L, Maggi L, Santarlasci V, Liotta F, Annunziato F (2014) $\mathrm{T}$ helper cells plasticity in inflammation. Cytometry 85:36-42

66. Schoenborn JR, Dorschner MO, Sekimata M, Santer DM, Shnyreva M, Fitzpatrick DR, Stamatoyannopoulos JA, Wilson CB (2007) Comprehensive epigenetic profiling identifies multiple distal regulatory elements directing transcription of the gene encoding interferon-gamma. Nat Immunol 8:732-742

67. Annunziato F, Cosmi L, Santarlasci V, Maggi L, Liotta F, Mazzinghi B, Parente E, Fili L, Ferri S, Frosali F et al (2007) Phenotypic and functional features of human Th17 cells. J Exp Med 204:1849-1861

68. Cosmi L, Maggi L, Santarlasci V, Capone M, Cardilicchia E, Frosali F, Querci V, Angeli R, Matucci A, Fambrini M et al (2010) Identification of a novel subset of human circulating memory $\mathrm{CD} 4(+) \mathrm{T}$ cells that produce both IL-17A and IL-4. J Allergy Clin Immunol 125:222-230.e221-224

69. Angiari S, Donnarumma T, Rossi B, Dusi S, Pietronigro E, Zenaro E, Della Bianca V, Toffali L, Piacentino G, Budui S et al (2014) TIM-1 glycoprotein binds the adhesion receptor P-selectin and mediates $\mathrm{T}$ cell trafficking during inflammation and autoimmunity. Immunity 40:542-553

70. Qin S, Rottman JB, Myers P, Kassam N, Weinblatt M, Loetscher M, Koch AE, Moser B, Mackay CR (1998) The chemokine receptors CXCR3 and CCR5 mark subsets of T cells associated with certain inflammatory reactions. J Clin Invest 101:746-754

71. Viola A, Luster AD (2008) Chemokines and their receptors: drug targets in immunity and inflammation. Annu Rev Pharmacol Toxicol 48:171-197

72. Nagata K, Tanaka K, Ogawa K, Kemmotsu K, Imai T, Yoshie O, Abe H, Tada K, Nakamura M, Sugamura K et al (1999) Selective expression of a novel surface molecule by human Th2 cells in vivo. J Immunol 162:1278-1286

73. Sallusto F, Lenig D, Mackay CR, Lanzavecchia A (1998) Flexible programs of chemokine receptor expression on human polarized $\mathrm{T}$ helper 1 and 2 lymphocytes. $\mathrm{J}$ Exp Med 187:875-883

74. Acosta-Rodriguez EV, Rivino L, Geginat J, Jarrossay D, Gattorno M, Lanzavecchia A, Sallusto F, Napolitani G (2007) Surface phenotype and antigenic specificity of human interleukin 17-producing $\mathrm{T}$ helper memory cells. Nat Immunol 8:639-646

75. Sato W, Aranami T, Yamamura T (2007) Cutting edge: human Th17 cells are identified as bearing CCR $2^{+}$CCR5- phenotype. J Immunol 178:7525-7529

76. Singh SP, Zhang HH, Foley JF, Hedrick MN, Farber JM (2008) Human $\mathrm{T}$ cells that are able to produce IL-17 express the chemokine receptor CCR6. J Immunol 180:214-221

77. Webb A, Johnson A, Fortunato M, Platt A, Crabbe T, Christie MI, Watt GF, Ward SG, Jopling LA (2008) Evidence for PI-3Kdependent migration of Th17-polarized cells in response to CCR2 and CCR6 agonists. J Leukoc Biol 84:1202-1212

78. Kara EE, Comerford I, Bastow CR, Fenix KA, Litchfield W, Handel TM, McColl SR (2013) Distinct chemokine receptor axes regulate Th9 cell trafficking to allergic and autoimmune inflammatory sites. J Immunol 191:1110-1117

79. Jiang X, Clark RA, Liu L, Wagers AJ, Fuhlbrigge RC, Kupper TS (2012) Skin infection generates non-migratory memory $\mathrm{CD}^{+} \mathrm{T}(\mathrm{RM})$ cells providing global skin immunity. Nature 483:227-231

80. Schenkel JM, Fraser KA, Masopust D (2014) Cutting edge: resident memory CD8 $\mathrm{T}$ cells occupy frontline niches in secondary lymphoid organs. J Immunol 192:2961-2964

81. Shin H, Iwasaki A (2012) A vaccine strategy that protects against genital herpes by establishing local memory $\mathrm{T}$ cells. Nature 491:463-467

82. Turner DL, Bickham KL, Thome JJ, Kim CY, D'Ovidio F, Wherry EJ, Farber DL (2014) Lung niches for the generation and maintenance of tissue-resident memory $\mathrm{T}$ cells. Mucosal Immunol 7:501-510 
83. Sathaliyawala T, Kubota M, Yudanin N, Turner D, Camp P, Thome JJ, Bickham KL, Lerner H, Goldstein M, Sykes M et al (2013) Distribution and compartmentalization of human circulating and tissue-resident memory $\mathrm{T}$ cell subsets. Immunity 38:187-197

84. Radulovic K, Niess JH (2015) CD69 is the crucial regulator of intestinal inflammation: a new target molecule for IBD treatment? J Immunol Res 2015:497056

85. Frost EL, Kersh AE, Evavold BD, Lukacher AE (2015) Cutting edge: resident memory CD8 T cells express high-affinity TCRs. J Immunol 195:3520-3524

86. Glennie ND, Yeramilli VA, Beiting DP, Volk SW, Weaver CT, Scott $\mathrm{P}$ (2015) Skin-resident memory $\mathrm{CD}^{+}{ }^{+} \mathrm{T}$ cells enhance protection against Leishmania major infection. J Exp Med 212:1405-1414

87. McMaster SR, Wilson JJ, Wang H, Kohlmeier JE (2015) Airway-resident memory $\mathrm{CD} 8 \mathrm{~T}$ cells provide antigen-specific protection against respiratory virus challenge through rapid IFNgamma production. J Immunol 195:203-209

88. Koyama SY, Podolsky DK (1989) Differential expression of transforming growth factors alpha and beta in rat intestinal epithelial cells. J Clin Invest 83:1768-1773

89. Pelton RW, Saxena B, Jones M, Moses HL, Gold LI (1991) Immunohistochemical localization of TGF beta 1 , TGF beta 2 , and TGF beta 3 in the mouse embryo: expression patterns suggest multiple roles during embryonic development. J Cell Biol 115:1091-1105

90. Zhang N, Bevan MJ (2013) Transforming growth factor-beta signaling controls the formation and maintenance of gut-resident memory $\mathrm{T}$ cells by regulating migration and retention. Immunity 39:687-696

91. Bankovich AJ, Shiow LR, Cyster JG (2010) CD69 suppresses sphingosine 1-phosophate receptor-1 (S1P1) function through interaction with membrane helix 4. J Biol Chem 285:22328-22337

92. Skon CN, Lee JY, Anderson KG, Masopust D, Hogquist KA, Jameson SC (2013) Transcriptional downregulation of S1pr1 is required for the establishment of resident memory $\mathrm{CD}^{+} \mathrm{T}$ cells. Nat Immunol 14:1285-1293

93. Mackay LK, Rahimpour A, Ma JZ, Collins N, Stock AT, Hafon ML, Vega-Ramos J, Lauzurica P, Mueller SN, Stefanovic T et al (2013) The developmental pathway for $\mathrm{CD} 103(+) \mathrm{CD}^{+}$tissueresident memory T cells of skin. Nat Immunol 14:1294-1301

94. Bromley SK, Yan S, Tomura M, Kanagawa O, Luster AD (2013) Recirculating memory $\mathrm{T}$ cells are a unique subset of $\mathrm{CD} 4^{+} \mathrm{T}$ cells with a distinct phenotype and migratory pattern. J Immunol 190:970-976

95. Iijima N, Iwasaki A (2014) T cell memory. A local macrophage chemokine network sustains protective tissue-resident memory CD4 T cells. Science 346:93-98

96. Walton SM, Mandaric S, Torti N, Zimmermann A, Hengel H, Oxenius A (2011) Absence of cross-presenting cells in the salivary gland and viral immune evasion confine cytomegalovirus immune control to effector CD4 T cells. PLoS Pathog 7:e1002214

97. Adachi T, Kobayashi T, Sugihara E, Yamada T, Ikuta K, Pittaluga S, Saya H (2015) Hair follicle-derived IL-7 and IL-15 mediate skin-resident memory $\mathrm{T}$ cell homeostasis and lymphoma. Nat Med 21:1272-1279

98. Mackay LK, Wynne-Jones E, Freestone D, Pellicci DG, Mielke LA, Newman DM, Braun A, Masson F, Kallies A, Belz GT et al (2015) T-box transcription factors combine with the cytokines TGF-beta and IL-15 to control tissue-resident memory T cell fate. Immunity 43:1101-1111

99. Hondowicz BD, An D, Schenkel JM, Kim KS, Steach HR, Krishnamurty AT, Keitany GJ, Garza EN, Fraser KA, Moon JJ et al (2016) Interleukin-2-dependent allergen-specific tissueresident memory cells drive asthma. Immunity 44:155-166

100. Bromley SK, Thomas SY, Luster AD (2005) Chemokine receptor CCR7 guides $\mathrm{T}$ cell exit from peripheral tissues and entry into afferent lymphatics. Nat Immunol 6:895-901

101. Guarda G, Hons M, Soriano SF, Huang AY, Polley R, MartinFontecha A, Stein JV, Germain RN, Lanzavecchia A, Sallusto F (2007) L-selectin-negative CCR7- effector and memory $\mathrm{CD}^{+}{ }^{+} \mathrm{T}$ cells enter reactive lymph nodes and kill dendritic cells. Nat Immunol 8:743-752. doi:10.1038/ni1469

102. Groom JR, Luster AD (2011) CXCR3 ligands: redundant, collaborative and antagonistic functions. Immunol Cell Biol 89:207-215

103. Mora JR, von Andrian UH (2006) T-cell homing specificity and plasticity: new concepts and future challenges. Trends Immunol 27:235-243

104. Weninger W, Crowley MA, Manjunath N, von Andrian UH (2001) Migratory properties of naive, effector, and memory CD8(+) T cells. J Exp Med 194:953-966

105. Jiang X, Campbell JJ, Kupper TS (2010) Embryonic trafficking of gammadelta $\mathrm{T}$ cells to skin is dependent on $\mathrm{E} / \mathrm{P}$ selectin ligands and CCR4. Proc Natl Acad Sci USA 107:7443-7448

106. Berg EL, Yoshino T, Rott LS, Robinson MK, Warnock RA, Kishimoto TK, Picker LJ, Butcher EC (1991) The cutaneous lymphocyte antigen is a skin lymphocyte homing receptor for the vascular lectin endothelial cell-leukocyte adhesion molecule 1. J Exp Med 174:1461-1466

107. Groves RW, Allen MH, Barker JN, Haskard DO, MacDonald DM (1991) Endothelial leucocyte adhesion molecule-1 (ELAM-1) expression in cutaneous inflammation. Br J Dermatol 124:117-123

108. Reiss Y, Proudfoot AE, Power CA, Campbell JJ, Butcher EC (2001) CC chemokine receptor (CCR) 4 and the CCR10 ligand cutaneous $\mathrm{T}$ cell-attracting chemokine (CTACK) in lymphocyte trafficking to inflamed skin. J Exp Med 194:1541-1547

109. Saeki H, Tamaki K (2006) Thymus and activation regulated chemokine (TARC)/CCL17 and skin diseases. J Dermatol Sci 43:75-84

110. Morales J, Homey B, Vicari AP, Hudak S, Oldham E, Hedrick J, Orozco R, Copeland NG, Jenkins NA, McEvoy LM et al (1999) CTACK, a skin-associated chemokine that preferentially attracts skin-homing memory $\mathrm{T}$ cells. Proc Natl Acad Sci USA 96:14470-14475

111. Batra A, Smith AC, Feehally J, Barratt J (2007) T-cell homing receptor expression in IgA nephropathy. Nephrol Dial Transplant 22:2540-2548. doi:10.1093/ndt/gfm228

112. Homey B, Alenius H, Muller A, Soto H, Bowman EP, Yuan W, McEvoy L, Lauerma AI, Assmann T, Bunemann E et al (2002) CCL27-CCR10 interactions regulate $\mathrm{T}$ cell-mediated skin inflammation. Nat Med 8:157-165

113. Alferink J, Lieberam I, Reindl W, Behrens A, Weiss S, Huser N, Gerauer K, Ross R, Reske-Kunz AB, Ahmad-Nejad P et al (2003) Compartmentalized production of CCL17 in vivo: strong inducibility in peripheral dendritic cells contrasts selective absence from the spleen. J Exp Med 197:585-599

114. Mirshahpanah P, Li YY, Burkhardt N, Asadullah K, Zollner TM (2008) CCR4 and CCR10 ligands play additive roles in mouse contact hypersensitivity. Exp Dermatol 17:30-34

115. Ariotti S, Haanen JB, Schumacher TN (2012) Behavior and function of tissue-resident memory T cells. Adv Immunol 114:203-216

116. Komori HK, Witherden DA, Kelly R, Sendaydiego K, Jameson JM, Teyton L, Havran WL (2012) Cutting edge: dendritic epidermal gammadelta $\mathrm{T}$ cell ligands are rapidly and locally expressed by keratinocytes following cutaneous wounding. J Immunol 188:2972-2976

117. Chodaczek G, Papanna V, Zal MA, Zal T (2012) Body-barrier surveillance by epidermal gammadelta TCRs. Nat Immunol $13: 272-282$ 
118. Girardi M, Lewis JM, Filler RB, Hayday AC, Tigelaar RE (2006) Environmentally responsive and reversible regulation of epidermal barrier function by gammadelta $\mathrm{T}$ cells. J Invest Dermatol 126:808-814

119. Jameson J, Ugarte K, Chen N, Yachi P, Fuchs E, Boismenu R, Havran WL (2002) A role for skin gammadelta T cells in wound repair. Science 296:747-749

120. Lahl K, Sweere J, Pan J, Butcher E (2014) Orphan chemoattractant receptor GPR15 mediates dendritic epidermal T-cell recruitment to the skin. Eur J Immunol 44:2577-2581

121. Jin Y, Xia M, Sun A, Saylor CM, Xiong N (2010) CCR10 is important for the development of skin-specific gammadeltaT cells by regulating their migration and location. J Immunol 185:5723-5731

122. Lefrancois L, Parker CM, Olson S, Muller W, Wagner N, Schon MP, Puddington L (1999) The role of beta7 integrins in CD8 T cell trafficking during an antiviral immune response. J Exp Med 189:1631-1638

123. Briskin M, Winsor-Hines D, Shyjan A, Cochran N, Bloom S, Wilson J, McEvoy LM, Butcher EC, Kassam N, Mackay CR et al (1997) Human mucosal addressin cell adhesion molecule-1 is preferentially expressed in intestinal tract and associated lymphoid tissue. Am J Pathol 151:97-110

124. Schweighoffer T, Tanaka Y, Tidswell M, Erle DJ, Horgan KJ, Luce GE, Lazarovits AI, Buck D, Shaw S (1993) Selective expression of integrin alpha 4 beta 7 on a subset of human $\mathrm{CD} 4^{+}$memory $\mathrm{T}$ cells with Hallmarks of gut-trophism. J Immunol 151:717-729

125. Wagner N, Lohler J, Kunkel EJ, Ley K, Leung E, Krissansen G, Rajewsky K, Muller W (1996) Critical role for beta7 integrins in formation of the gut-associated lymphoid tissue. Nature 382:366-370

126. Pabst O, Forster R, Lipp M, Engel H, Arnold HH (2000) NKX2.3 is required for MAdCAM-1 expression and homing of lymphocytes in spleen and mucosa-associated lymphoid tissue. EMBO J 19:2015-2023

127. Do JS, Visperas A, Freeman ML, Iwakura Y, Oukka M, Min B (2014) Colitogenic effector T cells: roles of gut-homing integrin, gut antigen specificity and gammadelta $\mathrm{T}$ cells. Immunol Cell Biol 92:90-98

128. Villablanca EJ, De Calisto J, Torregrosa Paredes P, Cassani B, Nguyen DD, Gabrielsson S, Mora JR (2014) beta7 integrins are required to give rise to intestinal mononuclear phagocytes with tolerogenic potential. Gut 63:1431-1440

129. Berer K, Boziki M, Krishnamoorthy G (2014) Selective accumulation of pro-inflammatory $\mathrm{T}$ cells in the intestine contributes to the resistance to autoimmune demyelinating disease. PLoS One 9:e87876

130. Califano D, Sweeney KJ, Le H, VanValkenburgh J, Yager E, O'Connor W Jr, Kennedy JS, Jones DM, Avram D (2014) Diverting $\mathrm{T}$ helper cell trafficking through increased plasticity attenuates autoimmune encephalomyelitis. J Clin Invest 124:174-187

131. Stenstad H, Svensson M, Cucak H, Kotarsky K, Agace WW (2007) Differential homing mechanisms regulate regionalized effector CD8alphabeta ${ }^{+} \mathrm{T}$ cell accumulation within the small intestine. Proc Natl Acad Sci USA 104:10122-10127. doi:10. 1073/pnas.0700269104

132. Kunkel EJ, Campbell JJ, Haraldsen G, Pan J, Boisvert J, Roberts AI, Ebert EC, Vierra MA, Goodman SB, Genovese MC et al (2000) Lymphocyte CC chemokine receptor 9 and epithelial thymus-expressed chemokine (TECK) expression distinguish the small intestinal immune compartment: epithelial expression of tissue-specific chemokines as an organizing principle in regional immunity. J Exp Med 192:761-768
133. Zabel BA, Agace WW, Campbell JJ, Heath HM, Parent D, Roberts AI, Ebert EC, Kassam N, Qin S, Zovko M et al (1999) Human G protein-coupled receptor GPR-9-6/CC chemokine receptor 9 is selectively expressed on intestinal homing $\mathrm{T}$ lymphocytes, mucosal lymphocytes, and thymocytes and is required for thymus-expressed chemokine-mediated chemotaxis. J Exp Med 190:1241-1256

134. Johansson-Lindbom B, Svensson M, Wurbel MA, Malissen B, Marquez G, Agace W (2003) Selective generation of gut tropic $T$ cells in gut-associated lymphoid tissue (GALT): requirement for GALT dendritic cells and adjuvant. J Exp Med 198:963-969

135. Stenstad H, Ericsson A, Johansson-Lindbom B, Svensson M, Marsal J, Mack M, Picarella D, Soler D, Marquez G, Briskin M et al (2006) Gut-associated lymphoid tissue-primed $\mathrm{CD}^{+} \mathrm{T}$ cells display CCR9-dependent and -independent homing to the small intestine. Blood 107:3447-3454

136. Kunkel EJ, Campbell DJ, Butcher EC (2003) Chemokines in lymphocyte trafficking and intestinal immunity. Microcirculation 10:313-323. doi:10.1038/sj.mn.7800196

137. Nishimura M, Kuboi Y, Muramoto K, Kawano T, Imai T (2009) Chemokines as novel therapeutic targets for inflammatory bowel disease. Ann N Y Acad Sci 1173:350-356. doi:10.1111/j.17496632.2009.04738.x

138. Koenecke C, Forster R (2009) CCR9 and inflammatory bowel disease. Expert Opin Ther Targets 13:297-306. doi:10.1517/ 14728220902762928

139. Papadakis KA, Prehn J, Nelson V, Cheng L, Binder SW, Ponath PD, Andrew DP, Targan SR (2000) The role of thymus-expressed chemokine and its receptor CCR9 on lymphocytes in the regional specialization of the mucosal immune system. J Immunol 165:5069-5076

140. Wurbel MA, Philippe JM, Nguyen C, Victorero G, Freeman T, Wooding P, Miazek A, Mattei MG, Malissen M, Jordan BR et al (2000) The chemokine TECK is expressed by thymic and intestinal epithelial cells and attracts double- and single-positive thymocytes expressing the TECK receptor CCR9. Eur J Immunol 30:262-271. doi:10.1002/(SICI)1521-4141(200001)30:01<262:AIDIMMU262>3.0.CO;2-M

141. Hosoe N, Miura S, Watanabe C, Tsuzuki Y, Hokari R, Oyama T, Fujiyama Y, Nagata H, Ishii H (2004) Demonstration of functional role of TECK/CCL25 in $\mathrm{T}$ lymphocyte-endothelium interaction in inflamed and uninflamed intestinal mucosa. Am J Physiol Gastrointest Liver Physiol 286:G458-G466

142. Wang C, Thangamani S, Kim M, Gu BH, Lee JH, Taparowsky EJ, Kim CH (2013) BATF is required for normal expression of gut-homing receptors by $\mathrm{T}$ helper cells in response to retinoic acid. J Exp Med 210:475-489

143. Kuklin NA, Rott L, Darling J, Campbell JJ, Franco M, Feng N, Muller W, Wagner N, Altman J, Butcher EC et al (2000) alpha(4)beta(7) independent pathway for CD8(+) T cell-mediated intestinal immunity to rotavirus. $\mathrm{J}$ Clin Invest 106:1541-1552. doi:10.1172/JCI10927

144. Kruglov AA, Grivennikov SI, Kuprash DV, Winsauer C, Prepens S, Seleznik GM, Eberl G, Littman DR, Heikenwalder M, Tumanov AV et al (2013) Nonredundant function of soluble LTalpha3 produced by innate lymphoid cells in intestinal homeostasis. Science 342:1243-1246

145. Fagarasan S, Kawamoto S, Kanagawa O, Suzuki K (2010) Adaptive immune regulation in the gut: $\mathrm{T}$ cell-dependent and $\mathrm{T}$ cell-independent IgA synthesis. Annu Rev Immunol 28:243-273

146. Wang X, Sumida H, Cyster JG (2014) GPR18 is required for a normal CD8alphaalpha intestinal intraepithelial lymphocyte compartment. J Exp Med 211:2351-2359

147. Kim SV, Xiang WV, Kwak C, Yang Y, Lin XW, Ota M, Sarpel U, Rifkin DB, Xu R, Littman DR (2013) GPR15-mediated 
homing controls immune homeostasis in the large intestine mucosa. Science 340:1456-1459

148. Danilova E, Skrindo I, Gran E, Hales BJ, Smith WA, Jahnsen J, Johansen FE, Jahnsen FL, Baekkevold ES (2015) A role for CCL28-CCR3 in T-cell homing to the human upper airway mucosa. Mucosal Immunol 8:107-114

149. Pan J, Kunkel EJ, Gosslar U, Lazarus N, Langdon P, Broadwell K, Vierra MA, Genovese MC, Butcher EC, Soler D (2000) A novel chemokine ligand for CCR10 and CCR3 expressed by epithelial cells in mucosal tissues. J Immunol 165:2943-2949

150. Wang W, Soto H, Oldham ER, Buchanan ME, Homey B, Catron D, Jenkins N, Copeland NG, Gilbert DJ, Nguyen N et al (2000) Identification of a novel chemokine (CCL28), which binds CCR10 (GPR2). J Biol Chem 275:22313-22323

151. Mikhak Z, Strassner JP, Luster AD (2013) Lung dendritic cells imprint $\mathrm{T}$ cell lung homing and promote lung immunity through the chemokine receptor CCR4. J Exp Med 210:1855-1869

152. Lim K, Hyun YM, Lambert-Emo K, Capece T, Bae S, Miller R, Topham DJ, Kim M (2015) Neutrophil trails guide influenzaspecific CD8(+) T cells in the airways. Science 349:aaa4352

153. Shannon B, Yi TJ, Thomas-Pavanel J, Chieza L, Janakiram P, Saunders M, Tharao W, Huibner S, Remis R, Rebbapragada A et al (2014) Impact of asymptomatic herpes simplex virus type 2 infection on mucosal homing and immune cell subsets in the blood and female genital tract. J Immunol 192:5074-5082

154. Freeman EE, Weiss HA, Glynn JR, Cross PL, Whitworth JA, Hayes RJ (2006) Herpes simplex virus 2 infection increases HIV acquisition in men and women: systematic review and metaanalysis of longitudinal studies. AIDS 20:73-83

155. Davila SJ, Olive AJ, Starnbach MN (2014) Integrin alpha4beta1 is necessary for $\mathrm{CD}^{+} \mathrm{T}$ cell-mediated protection against genital Chlamydia trachomatis infection. J Immunol 192:4284-4293

156. Bonder CS, Norman MU, Swain MG, Zbytnuik LD, Yamanouchi J, Santamaria P, Ajuebor M, Salmi M, Jalkanen S, Kubes P (2005) Rules of recruitment for Th1 and Th2 lymphocytes in inflamed liver: a role for alpha-4 integrin and vascular adhesion protein-1. Immunity 23:153-163

157. Arai K, Iiai T, Nakayama M, Hasegawa K, Sato K, Ohtsuka K, Watanabe H, Hanyu T, Takahashi HE, Abo T (1995) Adhesion molecules on intermediate TCR cells. I. Unique expression of adhesion molecules, CD44 ${ }^{+}$L-selectin-, on intermediate TCR cells in the liver and the modulation of their adhesion by hyaluronic acid. Immunology 84:64-71

158. Ribeiro S, Horuk R (2005) The clinical potential of chemokine receptor antagonists. Pharmacol Ther 107:44-58

159. Loetscher P, Uguccioni M, Bordoli L, Baggiolini M, Moser B, Chizzolini C, Dayer JM (1998) CCR5 is characteristic of Th1 lymphocytes. Nature 391:344-345

160. Luther SA, Cyster JG (2001) Chemokines as regulators of T cell differentiation. Nat Immunol 2:102-107

161. Carr DJ, Ash J, Lane TE, Kuziel WA (2006) Abnormal immune response of CCR5-deficient mice to ocular infection with herpes simplex virus type 1. J Gen Virol 87:489-499

162. Locati M, Murphy PM (1999) Chemokines and chemokine receptors: biology and clinical relevance in inflammation and AIDS. Annu Rev Med 50:425-440

163. Dawson TC, Beck MA, Kuziel WA, Henderson F, Maeda N (2000) Contrasting effects of CCR5 and CCR2 deficiency in the pulmonary inflammatory response to influenza A virus. Am J Pathol 156:1951-1959

164. Huser N, Tertilt C, Gerauer K, Maier S, Traeger T, Assfalg V, Reiter R, Heidecke CD, Pfeffer K (2005) CCR4-deficient mice show prolonged graft survival in a chronic cardiac transplant rejection model. Eur J Immunol 35:128-138
165. Hancock WW, Gao W, Csizmadia V, Faia KL, Shemmeri N, Luster AD (2001) Donor-derived IP-10 initiates development of acute allograft rejection. J Exp Med 193:975-980

166. Komarowska I, Coe D, Wang G, Haas R, Mauro C, Kishore M, Cooper D, Nadkarni S, Fu H, Steinbruchel DA et al (2015) Hepatocyte growth factor receptor c-Met instructs $\mathrm{T}$ cell cardiotropism and promotes $\mathrm{T}$ cell migration to the heart via autocrine chemokine release. Immunity 42:1087-1099

167. Mora JR, Bono MR, Manjunath N, Weninger W, Cavanagh LL, Rosemblatt M, Von Andrian UH (2003) Selective imprinting of gut-homing $\mathrm{T}$ cells by Peyer's patch dendritic cells. Nature 424:88-93

168. Stagg AJ, Kamm MA, Knight SC (2002) Intestinal dendritic cells increase $\mathrm{T}$ cell expression of alpha4beta7 integrin. Eur $\mathrm{J}$ Immunol 32:1445-1454

169. Campbell DJ, Butcher EC (2002) Rapid acquisition of tissuespecific homing phenotypes by $\mathrm{CD} 4(+) \mathrm{T}$ cells activated in cutaneous or mucosal lymphoid tissues. J Exp Med 195:135-141

170. Iwata M, Hirakiyama A, Eshima Y, Kagechika H, Kato C, Song SY (2004) Retinoic acid imprints gut-homing specificity on T cells. Immunity 21:527-538

171. Sigmundsdottir H, Butcher EC (2008) Environmental cues, dendritic cells and the programming of tissue-selective lymphocyte trafficking. Nat Immunol 9:981-987. doi:10.1038/ni.f. 208

172. Moore T (1930) Vitamin A and carotene: the absence of the liver oil vitamin A from carotene. VI. The conversion of carotene to vitamin A in vivo. Biochem J 24:692-702

173. Sigmundsdottir H, Pan J, Debes GF, Alt C, Habtezion A, Soler D, Butcher EC (2007) DCs metabolize sunlight-induced vitamin $\mathrm{D}_{3}$ to 'program' $\mathrm{T}$ cell attraction to the epidermal chemokine CCL27. Nat Immunol 8:285-293

174. Napoli JL (1999) Interactions of retinoid binding proteins and enzymes in retinoid metabolism. Biochim Biophys Acta 1440:139-162. pii: S1388-1981(99)00117-1

175. Duester G (2000) Families of retinoid dehydrogenases regulating vitamin A function: production of visual pigment and retinoic acid. Eur J Biochem 267:4315-4324. pii: ejb1497

176. Denning TL, Wang YC, Patel SR, Williams IR, Pulendran B (2007) Lamina propria macrophages and dendritic cells differentially induce regulatory and interleukin 17 -producing $\mathrm{T}$ cell responses. Nat Immunol 8:1086-1094

177. Coombes JL, Siddiqui KR, Arancibia-Carcamo CV, Hall J, Sun CM, Belkaid Y, Powrie F (2007) A functionally specialized population of mucosal CD $103^{+}$DCs induces Foxp $3^{+}$regulatory $\mathrm{T}$ cells via a TGF-beta and retinoic acid-dependent mechanism. J Exp Med 204:1757-1764. doi:10.1084/jem.20070590

178. Jaensson E, Uronen-Hansson H, Pabst O, Eksteen B, Tian J, Coombes JL, Berg PL, Davidsson T, Powrie F, JohanssonLindbom B et al (2008) Small intestinal CD103 ${ }^{+}$dendritic cells display unique functional properties that are conserved between mice and humans. J Exp Med 205:2139-2149

179. Johansson-Lindbom B, Svensson M, Pabst O, Palmqvist C, Marquez G, Forster R, Agace WW (2005) Functional specialization of gut $\mathrm{CD}_{103}{ }^{+}$dendritic cells in the regulation of tissueselective T cell homing. J Exp Med 202:1063-1073. doi:10. 1084/jem.20051100

180. Sun CM, Hall JA, Blank RB, Bouladoux N, Oukka M, Mora JR, Belkaid Y (2007) Small intestine lamina propria dendritic cells promote de novo generation of Foxp3 T reg cells via retinoic acid. J Exp Med 204:1775-1785. doi:10.1084/jem.20070602

181. Agace WW, Persson EK (2012) How vitamin A metabolizing dendritic cells are generated in the gut mucosa. Trends Immunol $33: 42-48$ 
182. Forster R, Pabst O, Bernhardt G (2008) Homeostatic chemokines in development, plasticity, and functional organization of the intestinal immune system. Semin Immunol 20:171-180. doi:10.1016/j.smim.2008.03.001

183. Coombes JL, Powrie F (2008) Dendritic cells in intestinal immune regulation. Nat Rev Immunol 8:435-446

184. Macpherson AJ, Uhr T (2004) Induction of protective IgA by intestinal dendritic cells carrying commensal bacteria. Science 303:1662-1665

185. Mowat AM (2003) Anatomical basis of tolerance and immunity to intestinal antigens. Nat Rev Immunol 3:331-341. doi:10. 1038/nri1057

186. Malmstrom V, Shipton D, Singh B, Al-Shamkhani A, Puklavec MJ, Barclay AN, Powrie F (2001) CD134L expression on dendritic cells in the mesenteric lymph nodes drives colitis in $\mathrm{T}$ cell-restored SCID mice. J Immunol 166:6972-6981

187. Hammerschmidt SI, Ahrendt M, Bode U, Wahl B, Kremmer E, Forster R, Pabst O (2008) Stromal mesenteric lymph node cells are essential for the generation of gut-homing $\mathrm{T}$ cells in vivo. J Exp Med 205:2483-2490. doi:10.1084/jem.20080039

188. Lampen A, Meyer S, Arnhold T, Nau H (2000) Metabolism of vitamin $\mathrm{A}$ and its active metabolite all-trans-retinoic acid in small intestinal enterocytes. J Pharmacol Exp Ther 295: 979-985

189. Ng SC, Kamm MA, Stagg AJ, Knight SC (2010) Intestinal dendritic cells: their role in bacterial recognition, lymphocyte homing, and intestinal inflammation. Inflamm Bowel Dis 16:1787-1807. doi:10.1002/ibd.21247

190. Guilliams M, Crozat K, Henri S, Tamoutounour S, Grenot $P$, Devilard E, de Bovis B, Alexopoulou L, Dalod M, Malissen B (2010) Skin-draining lymph nodes contain dermis-derived CD103(-) dendritic cells that constitutively produce retinoic acid and induce Foxp3(+) regulatory $\mathrm{T}$ cells. Blood 115:1958-1968

191. Ruane D, Brane L, Reis BS, Cheong C, Poles J, Do Y, Zhu H, Velinzon K, Choi JH, Studt N et al (2013) Lung dendritic cells induce migration of protective $\mathrm{T}$ cells to the gastrointestinal tract. J Exp Med 210:1871-1888

192. Manicassamy S, Ravindran R, Deng J, Oluoch H, Denning TL, Kasturi SP, Rosenthal KM, Evavold BD, Pulendran B (2009) Toll-like receptor 2-dependent induction of vitamin A-metabolizing enzymes in dendritic cells promotes $\mathrm{T}$ regulatory responses and inhibits autoimmunity. Nat Med 15:401-409

193. Saurer L, McCullough KC, Summerfield A (2007) In vitro induction of mucosa-type dendritic cells by all-trans retinoic acid. J Immunol 179:3504-3514

194. Darmanin S, Chen J, Zhao S, Cui H, Shirkoohi R, Kubo N, Kuge Y, Tamaki N, Nakagawa K, Hamada J et al (2007) All-trans retinoic acid enhances murine dendritic cell migration to draining lymph nodes via the balance of matrix metalloproteinases and their inhibitors. J Immunol 179:4616-4625

195. Lackey DE, Ashley SL, Davis AL, Hoag KA (2008) Retinoic acid decreases adherence of murine myeloid dendritic cells and increases production of matrix metalloproteinase-9. J Nutr 138:1512-1519

196. Ratzinger G, Stoitzner P, Ebner S, Lutz MB, Layton GT, Rainer C, Senior RM, Shipley JM, Fritsch P, Schuler G et al (2002) Matrix metalloproteinases 9 and 2 are necessary for the migration of Langerhans cells and dermal dendritic cells from human and murine skin. J Immunol 168:4361-4371

197. Lackey DE, Hoag KA (2010) Vitamin A upregulates matrix metalloproteinase- 9 activity by murine myeloid dendritic cells through a nonclassical transcriptional mechanism. J Nutr 140:1502-1508

198. Siewert C, Menning A, Dudda J, Siegmund K, Lauer U, Floess S, Campbell DJ, Hamann A, Huehn J (2007) Induction of organ- selective $\mathrm{CD}^{+}{ }^{+}$regulatory $\mathrm{T}$ cell homing. Eur $\mathrm{J}$ Immunol 37:978-989

199. Mora JR, Iwata M, Eksteen B, Song SY, Junt T, Senman B, Otipoby KL, Yokota A, Takeuchi H, Ricciardi-Castagnoli P et al (2006) Generation of gut-homing IgA-secreting B cells by intestinal dendritic cells. Science 314:1157-1160

200. Kang SG, Lim HW, Andrisani OM, Broxmeyer HE, Kim CH (2007) Vitamin A metabolites induce gut-homing FoxP3 ${ }^{+}$regulatory T cells. J Immunol 179:3724-3733. pii: 179/6/3724

201. Mora JR, von Andrian UH (2004) Retinoic acid: an educational "vitamin elixir" for gut-seeking T cells. Immunity 21:458-460

202. Yokota-Nakatsuma A, Takeuchi H, Ohoka Y, Kato C, Song SY, Hoshino T, Yagita H, Ohteki T, Iwata M (2014) Retinoic acid prevents mesenteric lymph node dendritic cells from inducing IL-13-producing inflammatory Th2 cells. Mucosal Immunol 7:786-801

203. Stock A, Booth S, Cerundolo V (2011) Prostaglandin E2 suppresses the differentiation of retinoic acid-producing dendritic cells in mice and humans. J Exp Med 208:761-773

204. Gretz JE, Norbury CC, Anderson AO, Proudfoot AE, Shaw S (2000) Lymph-borne chemokines and other low molecular weight molecules reach high endothelial venules via specialized conduits while a functional barrier limits access to the lymphocyte microenvironments in lymph node cortex. J Exp Med 192:1425-1440

205. McCully ML, Ladell K, Hakobyan S, Mansel RE, Price DA, Moser B (2012) Epidermis instructs skin homing receptor expression in human T cells. Blood 120:4591-4598

206. Greening JE, Tree TI, Kotowicz KT, van Halteren AG, Roep BO, Klein NJ, Peakman M (2003) Processing and presentation of the islet autoantigen GAD by vascular endothelial cells promotes transmigration of autoreactive T-cells. Diabetes 52:717-725

207. Marelli-Berg FM, Frasca L, Weng L, Lombardi G, Lechler RI (1999) Antigen recognition influences transendothelial migration of $\mathrm{CD}^{+} \mathrm{T}$ cells. J Immunol 162:696-703

208. Manes TD, Pober JS (2008) Antigen presentation by human microvascular endothelial cells triggers ICAM-1-dependent transendothelial protrusion by, and fractalkine-dependent transendothelial migration of, effector memory $\mathrm{CD} 4^{+} \mathrm{T}$ cells. J Immunol 180:8386-8392

209. Savinov AY, Wong FS, Stonebraker AC, Chervonsky AV (2003) Presentation of antigen by endothelial cells and chemoattraction are required for homing of insulin-specific $\mathrm{CD}^{+}$T cells. J Exp Med 197:643-656

210. Marelli-Berg FM, James MJ, Dangerfield J, Dyson J, Millrain M, Scott D, Simpson E, Nourshargh S, Lechler RI (2004) Cognate recognition of the endothelium induces HY-specific $\mathrm{CD}^{+}$T-lymphocyte transendothelial migration (diapedesis) in vivo. Blood 103:3111-3116

211. Savinov AY, Wong FS, Chervonsky AV (2001) IFN-gamma affects homing of diabetogenic T cells. J Immunol 167:6637-6643

212. Sobel RA, Blanchette BW, Bhan AK, Colvin RB (1984) The immunopathology of experimental allergic encephalomyelitis. II. Endothelial cell Ia increases prior to inflammatory cell infiltration. J Immunol 132:2402-2407

213. Walch JM, Zeng Q, Li Q, Oberbarnscheidt MH, Hoffman RA, Williams AL, Rothstein DM, Shlomchik WD, Kim JV, Camirand $\mathrm{G}$ et al (2013) Cognate antigen directs $\mathrm{CD}^{+} \mathrm{T}$ cell migration to vascularized transplants. $\mathrm{J}$ Clin Invest 123:2663-2671

214. Burbach BJ, Medeiros RB, Mueller KL, Shimizu Y (2007) T-cell receptor signaling to integrins. Immunol Rev 218:65-81

215. Laudanna C, Kim JY, Constantin G, Butcher E (2002) Rapid leukocyte integrin activation by chemokines. Immunol Rev 186:37-46 
216. Ticchioni M, Charvet C, Noraz N, Lamy L, Steinberg M, Bernard A, Deckert M (2002) Signaling through ZAP-70 is required for CXCL12-mediated T-cell transendothelial migration. Blood 99:3111-3118

217. Iwasaki M, Mukai T, Gao P, Park WR, Nakajima C, Tomura M, Fujiwara H, Hamaoka T (2001) A critical role for IL-12 in CCR5 induction on $\mathrm{T}$ cell receptor-triggered mouse CD4(+) and CD8(+) T cells. Eur J Immunol 31:2411-2420

218. Svensson M, Marsal J, Ericsson A, Carramolino L, Broden T, Marquez G, Agace WW (2002) CCL25 mediates the localization of recently activated CD8alphabeta $(+)$ lymphocytes to the small-intestinal mucosa. J Clin Invest 110:1113-1121

219. Kreisel D, Krasinskas AM, Krupnick AS, Gelman AE, Balsara KR, Popma SH, Riha M, Rosengard AM, Turka LA, Rosengard BR (2004) Vascular endothelium does not activate $\mathrm{CD} 4^{+}$direct allorecognition in graft rejection. J Immunol 173:3027-3034

220. Alegre ML, Frauwirth KA, Thompson CB (2001) T-cell regulation by CD28 and CTLA-4. Nat Rev Immunol 1:220-228

221. Shimizu Y, van Seventer GA, Ennis E, Newman W, Horgan KJ, Shaw S (1992) Crosslinking of the T cell-specific accessory molecules CD7 and CD28 modulates T cell adhesion. J Exp Med 175:577-582

222. Turcovski-Corrales SM, Fenton RG, Peltz G, Taub DD (1995) CD28:B7 interactions promote T cell adhesion. Eur J Immunol 25:3087-3093

223. Zell T, Hunt SW 3rd, Mobley JL, Finkelstein LD, Shimizu Y (1996) CD28-mediated up-regulation of beta 1-integrin adhesion involves phosphatidylinositol 3-kinase. J Immunol 156:883-886

224. Chang TT, Jabs C, Sobel RA, Kuchroo VK, Sharpe AH (1999) Studies in B7-deficient mice reveal a critical role for B7 costimulation in both induction and effector phases of experimental autoimmune encephalomyelitis. J Exp Med 190:733-740

225. Girvin AM, Dal Canto MC, Rhee L, Salomon B, Sharpe A, Bluestone JA, Miller SD (2000) A critical role for B7/CD28 costimulation in experimental autoimmune encephalomyelitis: a comparative study using costimulatory molecule-deficient mice and monoclonal antibody blockade. J Immunol 164:136-143

226. Salomon B, Bluestone JA (2001) Complexities of CD28/B7: CTLA-4 costimulatory pathways in autoimmunity and transplantation. Annu Rev Immunol 19:225-252

227. Mirenda V, Jarmin SJ, David R, Dyson J, Scott D, Gu Y, Lechler RI, Okkenhaug K, Marelli-Berg FM (2007) Physiologic and aberrant regulation of memory T-cell trafficking by the costimulatory molecule CD28. Blood 109:2968-2977

228. Okkenhaug K, Wu L, Garza KM, La Rose J, Khoo W, Odermatt B, Mak TW, Ohashi PS, Rottapel R (2001) A point mutation in CD28 distinguishes proliferative signals from survival signals. Nat Immunol 2:325-332

229. Bromley SK, Burack WR, Johnson KG, Somersalo K, Sims TN, Sumen C, Davis MM, Shaw AS, Allen PM, Dustin ML (2001) The immunological synapse. Annu Rev Immunol 19:375-396

230. Walker LS, Gulbranson-Judge A, Flynn S, Brocker T, Raykundalia C, Goodall M, Forster R, Lipp M, Lane P (1999) Compromised OX40 function in CD28-deficient mice is linked with failure to develop CXC chemokine receptor 5-positive CD4 cells and germinal centers. J Exp Med 190:1115-1122

231. Wei B, da Rocha Dias S, Wang H, Rudd CE (2007) CTLassociated antigen-4 ligation induces rapid $\mathrm{T}$ cell polarization that depends on phosphatidylinositol 3-kinase, Vav-1, Cdc42, and myosin light chain kinase. J Immunol 179:400-408

232. Okamoto N, Nukada Y, Tezuka K, Ohashi K, Mizuno K, Tsuji T (2004) AILIM/ICOS signaling induces T-cell migration/polarization of memory/effector T-cells. Int Immunol 16:1515-1522

233. Parry RV, Whittaker GC, Sims M, Edmead CE, Welham MJ, Ward SG (2006) Ligation of CD28 stimulates the formation of a multimeric signaling complex involving grb-2-associated binder
2 (gab2), SRC homology phosphatase-2, and phosphatidylinositol 3-kinase: evidence that negative regulation of $\mathrm{CD} 28$ signaling requires the gab2 pleckstrin homology domain. J Immunol 176:594-602

234. Okkenhaug K, Vanhaesebroeck B (2003) PI3K in lymphocyte development, differentiation and activation. Nat Rev Immunol 3:317-330

235. Jarmin SJ, David R, Ma L, Chai JG, Dewchand H, Takesono A Ridley AJ, Okkenhaug K, Marelli-Berg FM (2008) T cell receptor-induced phosphoinositide-3-kinase p110delta activity is required for $\mathrm{T}$ cell localization to antigenic tissue in mice. J Clin Invest 118:1154-1164

236. Okkenhaug K, Bilancio A, Farjot G, Priddle H, Sancho S, Peskett E, Pearce W, Meek SE, Salpekar A, Waterfield MD et al (2002) Impaired B and $T$ cell antigen receptor signaling in p110delta PI 3-kinase mutant mice. Science 297:1031-1034

237. Patton DT, Garden OA, Pearce WP, Clough LE, Monk CR, Leung E, Rowan WC, Sancho S, Walker LS, Vanhaesebroeck B et al (2006) Cutting edge: the phosphoinositide 3-kinase p110 delta is critical for the function of $\mathrm{CD}^{+} \mathrm{CD} 25^{+} \mathrm{Foxp} 3^{+}$regulatory T cells. J Immunol 177:6598-6602

238. Garcon F, Patton DT, Emery JL, Hirsch E, Rottapel R, Sasaki T, Okkenhaug K (2008) CD28 provides T-cell costimulation and enhances PI3K activity at the immune synapse independently of its capacity to interact with the p85/p110 heterodimer. Blood 111:1464-1471

239. Ying H, Fu H, Rose ML, McCormack AM, Sarathchandra $P$, Okkenhaug K, Marelli-Berg FM (2012) Genetic or pharmaceutical blockade of phosphoinositide 3-kinase p110delta prevents chronic rejection of heart allografts. PLoS One 7:e32892

240. Finlay D, Cantrell DA (2011) Metabolism, migration and memory in cytotoxic T cells. Nat Rev Immunol 11:109-117

241. Sinclair LV, Finlay D, Feijoo C, Cornish GH, Gray A, Ager A, Okkenhaug K, Hagenbeek TJ, Spits H, Cantrell DA (2008) Phosphatidylinositol-3-OH kinase and nutrient-sensing mTOR pathways control T lymphocyte trafficking. Nat Immunol 9:513-521

242. Kolsch V, Charest PG, Firtel RA (2008) The regulation of cell motility and chemotaxis by phospholipid signaling. J Cell Sci 121:551-559

243. Li J, Ballif BA, Powelka AM, Dai J, Gygi SP, Hsu VW (2005) Phosphorylation of ACAP1 by Akt regulates the stimulationdependent recycling of integrin beta1 to control cell migration. Dev Cell 9:663-673

244. Enomoto A, Murakami H, Asai N, Morone N, Watanabe T, Kawai K, Murakumo Y, Usukura J, Kaibuchi K, Takahashi M (2005) Akt/PKB regulates actin organization and cell motility via Girdin/APE. Dev Cell 9:389-402

245. Stambolic V, Woodgett JR (2006) Functional distinctions of protein kinase $\mathrm{B} / \mathrm{Akt}$ isoforms defined by their influence on cell migration. Trends Cell Biol 16:461-466

246. Ridley AJ, Schwartz MA, Burridge K, Firtel RA, Ginsberg MH, Borisy G, Parsons JT, Horwitz AR (2003) Cell migration: integrating signals from front to back. Science 302:1704-1709

247. Merlot S, Firtel RA (2003) Leading the way: directional sensing through phosphatidylinositol 3-kinase and other signaling pathways. J Cell Sci 116:3471-3478

248. Stephens L, Milne L, Hawkins P (2008) Moving towards a better understanding of chemotaxis. Curr Biol 18:R485-R494

249. Ward SG, Marelli-Berg FM (2009) Mechanisms of chemokine and antigen-dependent $\mathrm{T}$-lymphocyte navigation. Biochem $\mathrm{J}$ 418:13-27

250. Constantin G, Majeed M, Giagulli C, Piccio L, Kim JY, Butcher EC, Laudanna C (2000) Chemokines trigger immediate beta2 integrin affinity and mobility changes: differential regulation and roles in lymphocyte arrest under flow. Immunity 13:759-769 
251. Cinamon G, Shinder V, Alon R (2001) Shear forces promote lymphocyte migration across vascular endothelium bearing apical chemokines. Nat Immunol 2:515-522

252. Nombela-Arrieta C, Lacalle RA, Montoya MC, Kunisaki Y, Megias D, Marques M, Carrera AC, Manes S, Fukui Y, Martinez $\mathrm{AC}$ et al (2004) Differential requirements for DOCK2 and phosphoinositide-3-kinase gamma during $\mathrm{T}$ and $\mathrm{B}$ lymphocyte homing. Immunity 21:429-441

253. Sakaguchi S, Sakaguchi N, Asano M, Itoh M, Toda M (1995) Immunologic self-tolerance maintained by activated $\mathrm{T}$ cells expressing IL-2 receptor alpha-chains (CD25). Breakdown of a single mechanism of self-tolerance causes various autoimmune diseases. J Immunol 155:1151-1164

254. Sakaguchi S (2004) Naturally arising $\mathrm{CD}^{+}{ }^{+}$regulatory t cells for immunologic self-tolerance and negative control of immune responses. Annu Rev Immunol 22:531-562. doi:10.1146/ annurev.immunol.21.120601.141122

255. Bennett CL, Christie J, Ramsdell F, Brunkow ME, Ferguson PJ, Whitesell L, Kelly TE, Saulsbury FT, Chance PF, Ochs HD (2001) The immune dysregulation, polyendocrinopathy, enteropathy, X-linked syndrome (IPEX) is caused by mutations of FOXP3. Nat Genet 27:20-21. doi:10.1038/83713

256. Thornton AM, Shevach EM (2000) Suppressor effector function of $\mathrm{CD} 4{ }^{+} \mathrm{CD} 25^{+}$immunoregulatory $\mathrm{T}$ cells is antigen nonspecific. J Immunol 164:183-190

257. Brusko TM, Putnam AL, Bluestone JA (2008) Human regulatory $\mathrm{T}$ cells: role in autoimmune disease and therapeutic opportunities. Immunol Rev 223:371-390

258. Sakaguchi S (2011) Regulatory T cells: history and perspective. Methods Mol Biol 707:3-17

259. Ramsdell F, Ziegler SF (2003) Transcription factors in autoimmunity. Curr Opin Immunol 15:718-724. pii: S0952791503001456

260. Roncarolo MG, Levings MK (2000) The role of different subsets of $\mathrm{T}$ regulatory cells in controlling autoimmunity. Curr Opin Immunol 12:676-683

261. Baecher-Allan C, Brown JA, Freeman GJ, Hafler DA (2001) $\mathrm{CD} 4^{+} \mathrm{CD} 25$ high regulatory cells in human peripheral blood. J Immunol 167:1245-1253

262. Gavin MA, Torgerson TR, Houston E, DeRoos P, Ho WY, StrayPedersen A, Ocheltree EL, Greenberg PD, Ochs HD, Rudensky AY (2006) Single-cell analysis of normal and FOXP3-mutant human $\mathrm{T}$ cells: FOXP3 expression without regulatory $\mathrm{T}$ cell development. Proc Natl Acad Sci USA 103:6659-6664

263. Wang J, Ioan-Facsinay A, van der Voort EI, Huizinga TW, Toes RE (2007) Transient expression of FOXP3 in human activated nonregulatory $\mathrm{CD}^{+} \mathrm{T}$ cells. Eur $\mathrm{J}$ Immunol 37:129-138. doi:10.1002/eji.200636435

264. Sakaguchi S, Miyara M, Costantino CM, Hafler DA (2010) $\mathrm{FOXP}^{+}{ }^{+}$regulatory $\mathrm{T}$ cells in the human immune system. Nat Rev Immunol 10:490-500. doi:10.1038/nri2785

265. Khattri R, Cox T, Yasayko SA, Ramsdell F (2003) An essential role for Scurfin in $\mathrm{CD} 4{ }^{+} \mathrm{CD} 25^{+} \mathrm{T}$ regulatory cells. Nat Immunol 4:337-342

266. Chen W, Jin W, Hardegen N, Lei KJ, Li L, Marinos N, McGrady G, Wahl SM (2003) Conversion of peripheral CD4 ${ }^{+} \mathrm{CD} 25^{-}$ naive $\mathrm{T}$ cells to $\mathrm{CD} 4^{+} \mathrm{CD} 25^{+}$regulatory $\mathrm{T}$ cells by TGF-beta induction of transcription factor Foxp3. J Exp Med 198:1875-1886. doi:10.1084/jem.20030152

267. Curotto de Lafaille MA, Lino AC, Kutchukhidze N, Lafaille JJ (2004) $\mathrm{CD}_{25} 5^{-} \mathrm{T}$ cells generate $\mathrm{CD} 25^{+} \mathrm{Foxp}^{+}$regulatory $\mathrm{T}$ cells by peripheral expansion. J Immunol 173:7259-7268. pii: $173 / 12 / 7259$

268. Thorstenson KM, Khoruts A (2001) Generation of anergic and potentially immunoregulatory $\mathrm{CD} 25^{+} \mathrm{CD} 4 \mathrm{~T}$ cells in vivo after induction of peripheral tolerance with intravenous or oral antigen. J Immunol 167:188-195

269. Sallusto F, Lanzavecchia A (2009) Heterogeneity of $\mathrm{CD}^{+}$. memory T cells: functional modules for tailored immunity. Eur J Immunol 39:2076-2082. doi:10.1002/eji.200939722

270. Curotto de Lafaille MA, Kutchukhidze N, Shen S, Ding Y, Yee H, Lafaille JJ (2008) Adaptive Foxp3 ${ }^{+}$regulatory T cell-dependent and -independent control of allergic inflammation. Immunity 29:114-126. doi:10.1016/j.immuni.2008.05.010

271. Liu VC, Wong LY, Jang T, Shah AH, Park I, Yang X, Zhang Q, Lonning S, Teicher BA, Lee C (2007) Tumor evasion of the immune system by converting $\mathrm{CD}^{+} \mathrm{CD} 25^{-} \mathrm{T}$ cells into $\mathrm{CD} 4{ }^{+} \mathrm{CD} 25^{+} \mathrm{T}$ regulatory cells: role of tumor-derived TGFbeta. J Immunol 178:2883-2892. pii: 178/5/2883

272. Cobbold SP, Castejon R, Adams E, Zelenika D, Graca L, Humm $\mathrm{S}$, Waldmann $\mathrm{H}$ (2004) Induction of foxP3 ${ }^{+}$regulatory $\mathrm{T}$ cells in the periphery of $\mathrm{T}$ cell receptor transgenic mice tolerized to transplants. J Immunol 172:6003-6010

273. Zheng SG, Wang J, Wang P, Gray JD, Horwitz DA (2007) IL-2 is essential for TGF-beta to convert naive $\mathrm{CD}^{+}{ }^{+}$. J Immunol 178:2018-2027

274. Kopf H, de la Rosa GM, Howard OM, Chen X (2007) Rapamycin inhibits differentiation of Th17 cells and promotes generation of $\mathrm{FoxP}^{+}{ }^{+} \mathrm{T}$ regulatory cells. Int Immunopharmacol 7:1819-1824

275. Jhunjhunwala S, Chen LC, Nichols EE, Thomson AW, Raimondi G, Little SR (2013) All-trans retinoic acid and rapamycin synergize with transforming growth factor-beta1 to induce regulatory $\mathrm{T}$ cells but confer different migratory capacities. J Leukoc Biol 94:981-989

276. Ochando JC, Yopp AC, Yang Y, Garin A, Li Y, Boros P, Llodra J, Ding Y, Lira SA, Krieger NR et al (2005) Lymph node occupancy is required for the peripheral development of alloantigen-specific Foxp $^{+}$regulatory T cells. J Immunol 174:6993-7005

277. Graca L, Cobbold SP, Waldmann H (2002) Identification of regulatory $\mathrm{T}$ cells in tolerated allografts. $\mathrm{J}$ Exp Med 195:1641-1646

278. Lee I, Wang L, Wells AD, Dorf ME, Ozkaynak E, Hancock WW (2005) Recruitment of Foxp $3^{+}$T regulatory cells mediating allograft tolerance depends on the CCR4 chemokine receptor. J Exp Med 201:1037-1044

279. Bach JF (2003) Regulatory $T$ cells under scrutiny. Nat Rev Immunol 3:189-198

280. Luster AD (2002) The role of chemokines in linking innate and adaptive immunity. Curr Opin Immunol 14:129-135

281. Wood KJ, Sakaguchi S (2003) Regulatory T cells in transplantation tolerance. Nat Rev Immunol 3:199-210

282. Lim HW, Hillsamer P, Kim CH (2004) Regulatory T cells can migrate to follicles upon $\mathrm{T}$ cell activation and suppress GC-Th cells and GC-Th cell-driven B cell responses. J Clin Invest 114:1640-1649

283. Venturi GM, Conway RM, Steeber DA, Tedder TF (2007) $\mathrm{CD} 25^{+} \mathrm{CD} 4^{+}$regulatory $\mathrm{T}$ cell migration requires $\mathrm{L}$-selectin expression: L-selectin transcriptional regulation balances constitutive receptor turnover. J Immunol 178:291-300

284. Liston A, Rudensky AY (2007) Thymic development and peripheral homeostasis of regulatory T cells. Curr Opin Immunol 19:176-185

285. Huehn J, Siegmund K, Lehmann JC, Siewert C, Haubold U, Feuerer M, Debes GF, Lauber J, Frey O, Przybylski GK et al (2004) Developmental stage, phenotype, and migration distinguish naive- and effector/memory-like $\mathrm{CD} 4^{+}$regulatory $\mathrm{T}$ cells. J Exp Med 199:303-313

286. Agace WW, Higgins JM, Sadasivan B, Brenner MB, Parker CM (2000) T-lymphocyte-epithelial-cell interactions: integrin 
alpha(E)(CD103)beta(7), LEEP-CAM and chemokines. Curr Opin Cell Biol 12:563-568

287. Linterman MA, Pierson W, Lee SK, Kallies A, Kawamoto S, Rayner TF, Srivastava M, Divekar DP, Beaton L, Hogan JJ et al (2011) Foxp $3^{+}$follicular regulatory $\mathrm{T}$ cells control the germinal center response. Nat Med 17:975-982

288. Chung Y, Tanaka S, Chu F, Nurieva RI, Martinez GJ, Rawal S, Wang YH, Lim H, Reynolds JM, Zhou XH et al (2011) Follicular regulatory $\mathrm{T}$ cells expressing Foxp3 and Bcl-6 suppress germinal center reactions. Nat Med 17:983-988

289. Tang Q, Adams JY, Tooley AJ, Bi M, Fife BT, Serra P, Santamaria P, Locksley RM, Krummel MF, Bluestone JA (2006) Visualizing regulatory $\mathrm{T}$ cell control of autoimmune responses in nonobese diabetic mice. Nat Immunol 7:83-92

290. Bai Y, Liu J, Wang Y, Honig S, Qin L, Boros P, Bromberg JS (2002) L-selectin-dependent lymphoid occupancy is required to induce alloantigen-specific tolerance. J Immunol 168:1579-1589

291. Ermann J, Hoffmann P, Edinger M, Dutt S, Blankenberg FG, Higgins JP, Negrin RS, Fathman CG, Strober S (2005) Only the $\mathrm{CD}_{2} \mathrm{~L}^{+}$subpopulation of $\mathrm{CD}^{+}{ }^{+} \mathrm{CD} 25^{+}$regulatory $\mathrm{T}$ cells protects from lethal acute GVHD. Blood 105:2220-2226

292. Florek M, Schneidawind D, Pierini A, Baker J, Armstrong R, Pan Y, Leveson-Gower D, Negrin R, Meyer E (2015) Freeze and thaw of $\mathrm{CD}^{+} \mathrm{CD}^{2} 5^{+} \mathrm{Foxp}^{+}$regulatory $\mathrm{T}$ cells results in loss of CD62L expression and a reduced capacity to protect against graft-versus-host disease. PLoS One 10:e0145763

293. Szanya V, Ermann J, Taylor C, Holness C, Fathman CG (2002) The subpopulation of $\mathrm{CD} 4{ }^{+} \mathrm{CD} 25^{+}$splenocytes that delays adoptive transfer of diabetes expresses L-selectin and high levels of CCR7. J Immunol 169:2461-2465

294. Schneider MA, Meingassner JG, Lipp M, Moore HD, Rot A (2007) CCR7 is required for the in vivo function of $\mathrm{CD}^{+}{ }^{+}$ CD25 ${ }^{+}$regulatory T cells. J Exp Med 204:735-745

295. von Boehmer H (2005) Mechanisms of suppression by suppressor T cells. Nat Immunol 6:338-344

296. Liu Z, Gerner MY, Van Panhuys N, Levine AG, Rudensky AY, Germain RN (2015) Immune homeostasis enforced by co-localized effector and regulatory $\mathrm{T}$ cells. Nature 528:225-230

297. Siegmund K, Feuerer M, Siewert C, Ghani S, Haubold U, Dankof A, Krenn V, Schon MP, Scheffold A, Lowe JB et al (2005) Migration matters: regulatory T-cell compartmentalization determines suppressive activity in vivo. Blood 106:3097-3104

298. Schwarz A, Maeda A, Wild MK, Kernebeck K, Gross N, Aragane Y, Beissert S, Vestweber D, Schwarz T (2004) Ultraviolet radiation-induced regulatory $\mathrm{T}$ cells not only inhibit the induction but can suppress the effector phase of contact hypersensitivity. J Immunol 172:1036-1043

299. Abeynaike LD, Deane JA, Westhorpe CL, Chow Z, Alikhan MA, Kitching AR, Issekutz A, Hickey MJ (2014) Regulatory T cells dynamically regulate selectin ligand function during multiple challenge contact hypersensitivity. J Immunol 193:4934-4944

300. Angiari S, Rossi B, Piccio L, Zinselmeyer BH, Budui S, Zenaro E, Della Bianca V, Bach SD, Scarpini E, Bolomini-Vittori M et al (2013) Regulatory $T$ cells suppress the late phase of the immune response in lymph nodes through P-selectin glycoprotein ligand-1. J Immunol 191:5489-5500

301. Maly P, Thall A, Petryniak B, Rogers CE, Smith PL, Marks RM, Kelly RJ, Gersten KM, Cheng G, Saunders TL et al (1996) The alpha(1,3)fucosyltransferase Fuc-TVII controls leukocyte trafficking through an essential role in L-, E-, and P-selectin ligand biosynthesis. Cell 86:643-653

302. Erdmann I, Scheidegger EP, Koch FK, Heinzerling L, Odermatt B, Burg G, Lowe JB, Kundig TM (2002) Fucosyltransferase
VII-deficient mice with defective E-, P-, and L-selectin ligands show impaired $\mathrm{CD}_{4}^{+}$and $\mathrm{CD}^{+}{ }^{+} \mathrm{T}$ cell migration into the skin, but normal extravasation into visceral organs. J Immunol 168:2139-2146

303. Dudda JC, Martin SF (2004) Tissue targeting of T cells by DCs and microenvironments. Trends Immunol 25:417-421

304. Lehmann J, Huehn J, de la Rosa M, Maszyna F, Kretschmer U, Krenn V, Brunner M, Scheffold A, Hamann A (2002) Expression of the integrin alpha Ebeta 7 identifies unique subsets of $\mathrm{CD}^{+} 5^{+}$as well as. Proc Natl Acad Sci USA 99:13031-13036

305. Engelhardt BG, Jagasia M, Savani BN, Bratcher NL, Greer JP, Jiang A, Kassim AA, Lu P, Schuening F, Yoder SM et al (2010) Regulatory T cell expression of CLA or alpha(4)beta(7) and skin or gut acute GVHD outcomes. Bone Marrow Transplant 46:436-442

306. Lee JH, Kang SG, Kim CH (2007) FoxP3 $^{+}$T cells undergo conventional first switch to lymphoid tissue homing receptors in thymus but accelerated second switch to nonlymphoid tissue homing receptors in secondary lymphoid tissues. J Immunol 178:301-311

307. Iellem A, Colantonio L, D'Ambrosio D (2003) Skin-versus gutskewed homing receptor expression and intrinsic CCR4 expression on human peripheral blood CD $4{ }^{+} \mathrm{CD} 25^{+}$suppressor T cells. Eur J Immunol 33:1488-1496. doi:10.1002/eji.200323658

308. Hirahara K, Liu L, Clark RA, Yamanaka K, Fuhlbrigge RC, Kupper TS (2006) The majority of human peripheral blood $\mathrm{CD}^{+}{ }^{+} \mathrm{CD} 25$ highFoxp ${ }^{+}$regulatory $\mathrm{T}$ cells bear functional skinhoming receptors. J Immunol 177:4488-4494. pii: 177/7/4488

309. Valmori D, Merlo A, Souleimanian NE, Hesdorffer CS, Ayyoub M (2005) A peripheral circulating compartment of natural naive CD4 Tregs. J Clin Invest 115:1953-1962

310. Tomura M, Honda T, Tanizaki H, Otsuka A, Egawa G, Tokura Y, Waldmann H, Hori S, Cyster JG, Watanabe T et al (2010) Activated regulatory $\mathrm{T}$ cells are the major $\mathrm{T}$ cell type emigrating from the skin during a cutaneous immune response in mice. J Clin Invest 120:883-893

311. Shetty S, Weston CJ, Oo YH, Westerlund N, Stamataki Z, Youster J, Hubscher SG, Salmi M, Jalkanen S, Lalor PF et al (2011) Common lymphatic endothelial and vascular endothelial receptor-1 mediates the transmigration of regulatory $\mathrm{T}$ cells across human hepatic sinusoidal endothelium. J Immunol $186: 4147-4155$

312. Slifka MK, Antia R, Whitmire JK, Ahmed R (1998) Humoral immunity due to long-lived plasma cells. Immunity 8:363-372

313. Zou L, Barnett B, Safah H, Larussa VF, Evdemon-Hogan M, Mottram P, Wei S, David O, Curiel TJ, Zou W (2004) Bone marrow is a reservoir for $\mathrm{CD}^{+} \mathrm{CD}^{+} 5^{+}$regulatory $\mathrm{T}$ cells that traffic through CXCL12/CXCR4 signals. Cancer Res 64:8451-8455

314. Feuerer M, Beckhove P, Garbi N, Mahnke Y, Limmer A, Hommel M, Hammerling GJ, Kyewski B, Hamann A, Umansky $\mathrm{V}$ et al (2003) Bone marrow as a priming site for T-cell responses to blood-borne antigen. Nat Med 9:1151-1157

315. Burzyn D, Benoist C, Mathis D (2013) Regulatory T cells in nonlymphoid tissues. Nat Immunol 14:1007-1013

316. Sanchez Rodriguez R, Pauli ML, Neuhaus IM, Yu SS, Arron ST, Harris HW, Yang SH, Anthony BA, Sverdrup FM, Krow-Lucal E et al (2014) Memory regulatory T cells reside in human skin. J Clin Invest 124:1027-1036

317. Cipolletta D, Feuerer M, Li A, Kamei N, Lee J, Shoelson SE, Benoist C, Mathis D (2012) PPAR-gamma is a major driver of the accumulation and phenotype of adipose tissue Treg cells. Nature 486:549-553

318. Burzyn D, Kuswanto W, Kolodin D, Shadrach JL, Cerletti M, Jang Y, Sefik E, Tan TG, Wagers AJ, Benoist C et al (2013) A special population of regulatory $\mathrm{T}$ cells potentiates muscle repair. Cell 155:1282-1295 
319. Gratz IK, Campbell DJ (2014) Organ-specific and memory treg cells: specificity, development, function, and maintenance. Front Immunol 5:333

320. Fu H, Kishore M, Gittens B, Wang G, Coe D, Komarowska I, Infante E, Ridley AJ, Cooper D, Perretti M et al (2014) Selfrecognition of the endothelium enables regulatory $\mathrm{T}$-cell trafficking and defines the kinetics of immune regulation. Nat Commun 5:3436

321. Rosenblum MD, Gratz IK, Paw JS, Lee K, Marshak-Rothstein A, Abbas AK (2011) Response to self antigen imprints regulatory memory in tissues. Nature 480:538-542

322. Tang Q, Bluestone JA (2013) Regulatory T-cell therapy in transplantation: moving to the clinic. Cold Spring Harbor Perspect Med 3

323. Thome JJ, Bickham KL, Ohmura Y, Kubota M, Matsuoka N, Gordon C, Granot T, Griesemer A, Lerner H, Kato T et al (2016) Early-life compartmentalization of human $\mathrm{T}$ cell differentiation and regulatory function in mucosal and lymphoid tissues. Nat Med 22:72-77

324. Scharschmidt TC, Vasquez KS, Truong HA, Gearty SV, Pauli ML, Nosbaum A, Gratz IK, Otto M, Moon JJ, Liese J et al (2015) A wave of regulatory T cells into neonatal skin mediates tolerance to commensal microbes. Immunity 43:1011-1021
325. Levine AG, Arvey A, Jin W, Rudensky AY (2014) Continuous requirement for the TCR in regulatory $\mathrm{T}$ cell function. Nat Immunol 15:1070-1078

326. van Emmerik NE, Vaessen LM, Balk AH, Bos E, Claas FH, Weimar W (1996) Progressive accumulation of CTL with high avidity for donor antigens during the development of acute cardiac rejection. Transplantation 62:529-536

327. Wysocki CA, Jiang Q, Panoskaltsis-Mortari A, Taylor PA, McKinnon KP, Su L, Blazar BR, Serody JS (2005) Critical role for CCR5 in the function of donor $\mathrm{CD} 4^{+} \mathrm{CD} 25^{+}$regulatory $\mathrm{T}$ cells during acute graft-versus-host disease. Blood 106:3300-3307

328. Menning A, Loddenkemper C, Westendorf AM, Szilagyi B, Buer J, Siewert C, Hamann A, Huehn J (2010) Retinoic acidinduced gut tropism improves the protective capacity of Treg in acute but not in chronic gut inflammation. Eur $\mathrm{J}$ Immunol 40:2539-2548. doi:10.1002/eji.200939938

329. Morrison LA, Da Costa XJ, Knipe DM (1998) Influence of mucosal and parenteral immunization with a replication-defective mutant of HSV-2 on immune responses and protection from genital challenge. Virology 243:178-187 